\title{
Thyroid hormones and the central nervous system of mammals (Review)
}

\author{
ITALIA DI LIEGRO \\ Dipartimento di Scienze Biochimiche, Università degli Studi di Palermo, Palermo, Italy \\ Received January 14, 2008; Accepted February 29, 2008
}

\begin{abstract}
The thyroid hormones (THs) L-thyroxine (T4) and L-triiodothyronine (T3) have a profound influence on the development and maturation of the mammalian brain, both before and after birth. Any impairment in the supply of THs to the developing nervous system leads to severe and irreversible changes in both the overall architecture and functions of the brain and causes, in humans, neurological and motor deficits known as cretinism. Pronounced neurological symptoms are also commonly observed in adult patients suffering from both hyperthyroidism and hypothyroidism, and it has recently emerged that certain symptoms might result from the reduced brain uptake, rather than the insufficient production, of THs. Most of the effects of THs are mediated by two classes of nuclear receptors ( $\alpha$ and $B$ isoforms), which belong to the c-erbA superfamily of transcriptional regulators and are expressed in a tissue-specific and developmentally regulated manner. Interestingly, the nuclear TH receptors (nTRs) act as both ligand-independent gene repressors and ligand-dependent gene activators. On the other hand, negatively-regulated genes, which can be stimulated in the absence of THs and repressed by THs, have also been observed. Due to this complex pattern of regulation, the effects of receptor dysfunction do not exactly overlap the effects of hormone deficiency or excess. Moreover, non-genomic mechanisms of TH action have been described in many tissues, including the brain, some of which seem to be mediated by integrins and to be calcium-dependent. Intracellular receptors, distinct from nTRs, are present in the mitochondria, where a matrix-associated, T3-dependent transcriptional regulator of approximately $43 \mathrm{kDa}$ has been described. Finally, complex patterns of pituitary and/or peripheral resistance to thyroid hormones (RTH), characterized by elevated plasma levels of THs and non-suppressible thyroidstimulating hormone (TSH), have been identified. This review summarizes the major advances in knowledge of the molecular
\end{abstract}

Correspondence to: Dr Italia Di Liegro, Dipartimento di Scienze Biochimiche, Università degli Studi di Palermo, Via del Vespro 129, I-90127 Palermo, Italy

E-mail: diliegro@unipa.it

Key words: thyroid hormones, brain development, brain functions, central nervous system, nuclear receptors, non-genomic actions mechanisms of $\mathrm{TH}$ action and their implication for the effects of THs on the developing, as well as the adult mammalian, nervous system.

\section{Contents}

1. Introduction

2. Thyroid hormone supply to the fetus

3. General mechanisms of thyroid hormone action

4. Thyroid hormone synthesis, transport and uptake into the brain

5. Resistance to thyroid hormones

6. Thyroid hormone effects on the nervous system

7. Conclusions

\section{Introduction}

Thyroid hormones (THs), which are found in all chordate animals, are major regulators of normal brain development. Within a century, the contributions of varied disciplines - from biochemistry and physiology to molecular genetics and clinical medicine - definitively linked cretinism and certain neurological disorders of the adult human to impaired thyroid function. The first step in this direction was a report published by the Clinical Society of London in 1888; following its release, sheep thyroid extracts began to be used to treat hypothyroidism (1). In 1914, Kendall isolated thyroxine from thyroid extracts (2) and, in 1954, Gross and Pitt-Rivers synthesized T3 for the first time (3).

In subsequent decades, it became increasingly clear that THs act by binding to intracellular receptors, much as steroid hormones do (1,4-16). Indeed, when glucocorticoid- (17) and oestrogen- (18) receptors, as well as TH receptors (TRs) $(19,20)$, were finally cloned in the 1980 s, it became evident that they all belong to the same family of structurally-related nuclear proteins, capable of recognizing specific DNA response elements present in the 5'-flanking regions of target gene promoters. In particular, TRs were identified as the products of the cellular c-erbA $\alpha$ and $\beta$ proto-oncogenes present on human chromosomes 17 and 3 , respectively $(19,20)$. At the same time, it was demonstrated that some alternative splicing products of the c-erbA $\alpha$ gene do not have a hormone-binding domain (21-24). Curiously, one of these forms (c-erbA $\alpha 2$ ) is highly enriched in the brain $(25,26)$. Despite the two strains of evidence suggesting, on the one hand, that THs are fundamental 
to brain development and activity, and, on the other, that they act mainly by binding nuclear receptors, only a few genes are known to be directly regulated by THs in the nervous system. Expression of some of these genes is delayed only by hypothyroidism, and eventually reaches euthyroid-similar expression levels (27). Nonetheless, the damage done to the brain is irreversible, suggesting that the precise timing of the expression of such genes is more important than their final expression levels.

\section{Thyroid hormone supply to the fetus}

In 1949, Weiss and Noback reported that, when pregnant rats were treated with thiouracil (an inhibitor of the peroxidase involved in $\mathrm{TH}$ synthesis), the appearance of ossification centers in 16-day-old fetuses was delayed (28). The authors suggested that THs of maternal origin might be involved in fetal development prior to the onset of fetal thyroid activity. The idea that maternal thyroid function is important to the child was not actually new; at the beginning of the 20th century, physicians in different parts of the world involved in severe endemic goiter and cretinism hypothesized that maternal thyroid status had an effect on fetal development. Since, however, the mammalian placenta was believed to form a barrier to THs, the effects of maternal hypothyroidism on fetal development were attributed by other researchers to a general inability of the hypothyroid mother to maintain sufficient placental function, and hence a good nutrient supply, to the fetus (discussed in ref. 29). In biochemical terms, this barrier results from the known activity of the selenocysteine iodothyronine monodeiodinase enzymes (30), particularly of type 3 iodothyronine deiodinase (D3 enzyme) which, through deiodination of the inner-ring 5 position, inactivate both $\mathrm{T} 4$ and T3 by transforming them into 3,3',5'-triiodothyronine (reverse T3; rT3) and 3,3'-diiodothyronine (rT2), respectively (31). The D3 gene is highly expressed in the human utero-placental unit and might limit TH transfer from the mother to the fetus (32).

Then, in the 1970s and 1980s, the transplacental transfer of both L-T4 and L-T3 was demonstrated by many groups, suggesting that T4 and T3 found in early embryotrophoblasts, embryos and placentas were indeed produced by the mother (29,33-40). In addition, it was demonstrated that early maternal thyroxinemia altered the histogenesis and cytoarchitecture of the brain cortex (38). In more recent years, it has been definitively accepted that fetal tissues are exposed to biologicallyrelevant free THs during the first trimester of pregnancy (i.e., before the onset of fetal thyroid function) $(41,42)$. At the same time, the key role of the deiodinases, in particular D2 and D3, has been confirmed. These enzymes are integral membrane proteins of the endoplasmic reticulum and the plasma membrane, with active sites exposed to the cytoplasm (30). D2 is less concentrated than D3 and is predominantly found in the villous cytotrophoblast layer, suggesting this enzyme isotype plays a role in the supply of active hormone to the fetoplacental unit (41). On the other hand, D3 is expressed in the villous syncytiotrophoblast layer, in contact with the maternal blood (41). It is likely that D3 plays a role in protecting the fetus from an excess of TH transfer from the mother ('barrier' effect) $(31,32,41,43-45)$. In addition, this enzyme isotype might be involved in the release of iodine into fetal circulation for late TH production (41). The concentration of both proteins decreases during gestation.

A complementary approach to understanding the importance of hormone transfer from the mother to the fetus has been the study of the proteins directly involved in the transfer itself. THs, given their lipophilic character, were assumed for a long time to cross the plasma membrane by passive diffusion though the lipid bilayer. However, the large body of evidence that has accumulated over time shows without a doubt that specific transporters are involved in both the uptake and the export of these hormones through cell membranes (see section 4, 'Thyroid hormone synthesis, transport and uptake into the brain'). Although, to date, few reports have been published concerning the specific transporter responsible for $\mathrm{TH}$ transport across the human placenta, there is evidence to support the involvement of different classes of membrane proteins, such as the organic anion-transporting polypeptides (OATPs), the L-type amino acid transporter (LAT1) and the monocarboxylate transporter family (MCT8) (discussed in ref. 41).

\section{General mechanisms of thyroid hormone action}

The molecular mechanisms by which THs regulate cell functions have been investigated using two complementary approaches: i) by directly probing the hormone-binding activity of tissue extracts, and ii) by analyzing the effects of hormone withdrawal or addition, both in vivo and in vitro. One initial general conclusion (discussed in ref. 46) from both lines of study was that THs, like steroids, exert their effects after a time lag, during which RNA and protein synthesis is very often required. However, certain cellular activities were found to be immediately stimulated by THs. At the same time, it was found that hormone-binding sites were present in different subcellular compartments.

Nuclear TH receptors and TH effects on genome structural organization: corepressors, coactivators and chromatin remodelling. Since the 1980 s, most of the available evidence has demonstrated that THs act predominantly through interaction with nuclear TH receptors (nTRs) of high affinity and limited capacity, which exhibit a higher affinity for T3 than for T4 (47-50). In 1986, the genes encoding these receptors were independently cloned in two laboratories $(19,20)$, and were found to correspond to the cellular homologues of the viral oncogene v-erbA. In the following years, they were demonstrated to belong to a larger superfamily of nuclear receptors (NRs) that included the receptors for retinoic acid, vitamin D, steroid hormones, peroxisomal proliferator receptors (PPARs), as well as 'orphan' receptors (i.e., receptors for which a ligand has not yet been found). All these proteins share a general domain organization: six regions (A-F), two of which (C and E) are highly conserved and correspond, respectively, to a central DNA-binding domain that contains two zinc-fingers, and to a carboxy-terminal ligand-binding domain (51) that also contains multiple contact surfaces involved in receptor dimerization and interaction with other regulatory proteins $(1,52-55)$.

Two different genes, THRA and THRB, encode $\alpha$ and $\beta$ isoforms, respectively, and give rise, by alternate splicing, to a variety of proteins. Four of these $(\alpha 1, \beta 1, \beta 2$ and $\beta 3)$ are functional receptors, while others (for example $\alpha 2$ ) do not 


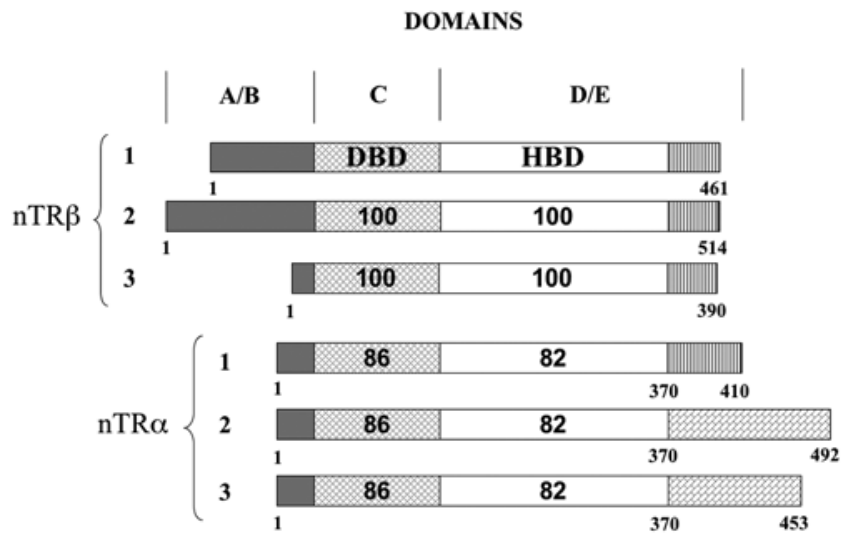

Figure 1. Schematic summary of the domain structure of nTR proteins. Percentages of homology in the DNA- (DBD) and the hormone- (HBD) binding domains, in comparison with the nTRß1 isoform, are shown. The numbers under the bars refer to amino acid positions $(51,139)$.

bind THs. Fig. 1 provides a general summary of the domain structure of the main $\mathrm{NTR} \beta$ and $\alpha$.

The effects of NRs are primarily due to interaction with specific DNA sequences known as TH response elements (TREs) that are present in the regulatory regions of a variety of target genes (1,54-59) and consist of two half sites each formed by at least the AGGTCA consensus motif (56-59). Most TREs are direct repeats of this consensus sequence, generally separated by 4 nucleotides, but other types of combinations (i.e., head-to-head and inverted tail-to-tail repeats), spaced by different numbers of nucleotides, are also possible (60). The hexamer motifs present in the naturally-occurring TREs show a relatively low sequence conservation, suggesting that divergence of the repeats might be a way to modulate the degree of $\mathrm{TH}$ responsiveness of different target genes (57).

Unlike steroid receptors, which form homodimers, nTRs preferentially form heterodimers with the retinoid $\mathrm{X}$ receptor (RXR), another member of the NR family. RXR proteins, which bind the 5 ' half repeat, enhance nTR binding to the 3 ' repeat on DNA by reducing its dissociation rate $(59,60)$. However, nTRs have also been known to bind to structurally different response elements as monomers and homodimers (61-63). The ability of nTR dimers to bind TREs in such different combinations suggests a flexible protein structure; indeed, it has recently been proposed that the nTR D-domain has the potential to form functionally-important extensions, or even to unfold to permit nTR adaptation to different DNA response elements (64). Moreover, certain nTR isoforms, such as TR $\beta$, have been reported to bind as trimers to a subset of naturally-occurring DNA elements (65). This mode of TRE binding also results in an enhanced recruitment of coactivators in vitro and in increased transcriptional activation (65).

Most of the known TREs are 'positive' regulators at which transcription is repressed by T3-free nTRs and activated by T3bound nTRs. A few TREs are 'negative' regulators, at which transcription is stimulated by hormone-free TRs and repressed by hormone-bound TRs $(52-54,57,58)$.

The interaction between nTRs and other NRs has been demonstrated by different experimental approaches. For example, nTRs interact with PPARs by sharing both binding sites and heterodimeric partners, such as RXR (66).
The ability of THs to induce chromatin structural modifications has been known for some time, since it was discovered that transcriptionally-active genes have sites of increased sensitivity to DNase I. These are called hypersensitive sites $(67,68)$ and can be induced, by $\mathrm{TH}$ treatment, in some $\mathrm{TH}-$ responsive genes, such as the growth hormone gene in pituitary cells (69) and the gene encoding the malic enzyme in rat liver (70).

More recently, the negative and positive transcriptional effects of TRs were demonstrated to depend on their interaction with co-repressors and coactivators, respectively (1,51-55,57, 58,71-77). The identified coactivators for nTR action include: i) at least two proteins belonging to the p160 family, the steroid receptor coactivator 1 (SRC-1), also called nuclear coactivator $1(\mathrm{NCoA}-1)$ and the transcriptional intermediary factor 2 (TIF2/GRIP-1/NCoA-2), ii) the cAMP-response elementbinding protein (CREB)-binding protein, also known as p300, and the related $\mathrm{p} 300 / \mathrm{CBP}$-associated factor ( $\mathrm{p} / \mathrm{CAF})$, and iii) the so-called vitamin D receptor interacting protein/TR-associated proteins (DRIP/TRAPs). Most coactivators can bind different NRs and also a variety of other transcription factors (53) such as CREB, the signal transducer and activator of transcription (STAT) proteins, and the nuclear factor $\kappa \mathrm{B}(\mathrm{NF}-\kappa \mathrm{B})$. Indeed, combinatorial regulation of transcription involves not only the binding of transcription factors to DNA, but also protein-protein interactions among factors with different, sometimes opposite, effects. This phenomenon is indicated as transcriptional cross-talk. For example, a mutual transcription antagonism has been found to exist between TRs and CREB; TR inhibits the cyclic AMP (cAMP)-dependent transcriptional activity of CREB without directly competing with it to bind to cAMP-responsive elements. However, by binding to CREB, T3-bound TR inhibits PKA-dependent phosphorylation and the activation of CREB (78). Notably, in neuroblastoma cells, T3-bound TRs are also able to antagonize the transcriptional response mediated by oncogenic Ras (79) and to induce the down-regulation of the c-myc gene and of cyclin D1 levels, as well as inducing a sustained increase in the cyclin kinase inhibitor p27 (kip1) (80).

Many coactivators possess histone acetyltransferase (HAT) activity which, in the case of $\mathrm{p} / \mathrm{CAF}$, is primarily directed at $\mathrm{H} 3$ and $\mathrm{H} 4$ histones (81-83). As the hyperacetylation of histones correlates with chromatin remodelling and gene activation, these coactivators can have direct effects on chromatin structural organization, which presumably facilitates the access of transcription factors to gene promoters. However, in some cases chromatin remodelling has been shown to be necessary but not sufficient for transcription stimulation, and occasionally chromatin disruption is not required at all. Thus, as HATs can also acetylate other non-histone proteins, such as p53 or the basal transcription factors TFIIE and TFIIF, gene activation by nTRs might involve different steps and mechanisms for different genes (53). In contrast with general coactivators, which are able to bind many NRs and transcriptional factors, the NR-interacting factor 3 (NRIF3) seems to bind specifically to TR/RXR (84).

When bound to 'positive' TREs in the hormone-free form, nTRs are part of protein complexes that include corepressors, such as the nuclear corepressor (NCoR) and the silencing mediator for RXR and TR (SMRT). Besides NCoR and SMR, 
the corepressor complex can also include mSin3A and histone deacetylases which, in turn, associate with methyl-CpGbinding proteins, thus mediating methylation-dependent gene silencing (85-87). Repression of NR activity by SMRT and NCoR is crucial for development. For example, targeted elimination of mouse NCoR is lethal to the embryo, which develops defects of the central nervous system (CNS) and blood tissue (87), as well as impaired self-renewal of neural stem cells (88). Moreover, it has been reported that Xenopus embryos lacking specific SMRT isoforms develop abnormal heads (89).

Certain genes, such as those encoding TRH, TSH $\alpha$ - and TSHß-subunit and prolactin, contain 'negative' TREs by which transcription is repressed by hormone-bound nTRs and activated by hormone-free nTRs. It has been found that nTRs bind weakly to the putative negative TREs, and it is not yet clear whether regulation depends on direct nTR binding or on protein-protein interaction with other factors (83). For example, nTRs can inhibit binding to the promoter of transcription factors like AP-1. They can also interact with a recently discovered class of ligand-dependent corepressors (LCoRs) that were found to be able to bind a wide variety of NRs (90). In general, however, the precise changes in chromatin organization that occur during negative regulation by $\mathrm{THs}$ are not yet well characterized.

As mentioned, there are two distinct genes (TR $\alpha$ and TR $\beta$ ) for nTRs from which a variety of isoforms are generated in many species, such as amphibians, chickens, rats, mice and humans (1). Alternative splicing of the primary transcript of the $\mathrm{TR} \alpha$ gene generates $n \mathrm{TR} \alpha-1$ and c-erbA $\alpha 2$. In the rat, the two proteins are identical through the first 370 amino acids, but completely diverge thereafter $(21-24,26)$. A third form (TRVII or $\alpha 3$ ) is identical to $\alpha 2$ but lacks the first 39 amino acids of the $\alpha 2$-specific region (24). The $\alpha 2$ isoform does not bind THs because it lacks amino acids critical to binding (21-24). In addition, it shows changes in dimerization ability and reduced DNA affinity (91-94). Given these properties and its ability to inhibit nTR $\alpha / \mathrm{TR} \beta$ in transiently transfected cells, c-erbA $\alpha 2$ protein has been suggested to be a physiological modulator/ inhibitor of nTH function (22).

Interestingly, the nTR $\alpha$ gene encodes yet another protein, known as Rev-erbA, on the opposite strand with respect to the one encoding the main $\alpha$ proteins $(22,95)$. Rev-erbA also belongs to the family of NRs and possesses a ligand-binding domain. The actual ligand of this protein is not known, and it is classified as an 'orphan' receptor (96). As Rev-erbA mRNA is partially complementary to mRNAs encoding the main $\alpha$ proteins, it is possible that it modulates the transcription and/or maturation of these transcripts.

The TRß gene encodes two main TR $\beta$ isoforms, $\beta 1$ and $\beta 2$, which are derived from alternative promoters. The two proteins diverge at the $\mathrm{N}$-terminus but are identical for most of their amino acid sequence and for their DNA-binding properties $(1,83)$.

Both nTR $\alpha 1$ and nTR $\beta 1$ are expressed in almost all tissues. There are, however, a few significant differences in their abundances. nTR $\alpha 1$ has the highest expression in skeletal and cardiac muscles, as well as in brown fat, while nTRß1 is more concentrated in the liver, kidney and brain. nTR $\alpha 2$ expression is highest in the brain and testis, and nTRß2 expression is restricted to the anterior pituitary, hypothalamus and cochlea
$(1,83)$. Differences have also been found in the timing of expression during development. In spite of these differences, it is not yet known whether different nTR isoforms have different effects on transcription.

TH-binding sites at the plasma membrane and TH nongenomic effects. Besides TH action mediated by nTRs and involving direct regulation of target gene transcription, a number of rapid TH effects, which cannot be mediated by genomic action and take place outside the nucleus, are becoming increasingly evident (97-106). These non-genomic responses are often mediated by secondary messengers, such as diacyl glycerol, inositol trisphosphate (IP3), $\mathrm{Ca}^{++}$ions and cAMP.

By the 1960s and 1970s, the existence of TH-binding sites at the plasma membrane had already been reported (discussed in ref. 46), and some of these sites were proposed to be involved in triggering early hormonal effects, such as increased uptake of amino acids, nucleosides and glucose into target cells (107-112). However, over the following decades, after the identification and cloning of the genes encoding nTRs, most work focused on the nuclear pathway of $\mathrm{TH}$ action. More recently, the extranuclear mode of action has been widely acknowledged on the basis of a variety of lines of evidence, including the rapid onset of responses (from seconds to minutes), occurrence even after transcriptional blockage, and the involvement of plasma membrane signalling pathways. Although the specific targets and molecular mechanisms of non-genomic action remain unclear, its existence is evident. In L-6 myoblasts and chick embryo hepatocytes, for example, THs have been shown to stimulate, by a non-genomic mechanism, the activity of the $\mathrm{Na}^{+} / \mathrm{H}^{+}$exchanger type 1 (NHE-1) (102). NHE-1 is a key phosphoglycoprotein that, besides having a housekeeping role in the maintenance of intracellular $\mathrm{pH}$ and cell volume, is involved in regulatory events triggered by different growth-stimulating signals (102). The use of various inhibitors, able to block specific steps of the intracellular signal transduction pathway, has facilitated the demonstration of the involvement of PKC and the MAPK pathway in the activation of NHE-1 by THs (113). Through the formation of IP3, THs also mobilize intracellular calcium ions (102). In a rat pituitary cell line, THs stimulated phosphatidylinositol 3-kinase (PI3K) and Rac activity, which in turn stimulated voltageactivated potassium channels $(83,114)$. Notably, in this latter case, T3 was found to reduce the interaction between the regulatory subunit $\mathrm{p} 85 \alpha$ of $\mathrm{PI} 3 \mathrm{~K}$ and $\mathrm{nTR} \beta$ at the plasma membrane (83). In other cases, the activation of PI3K and its downstream signalling cascade was triggered by liganded TRß in the cytosol (105).

The search for the identity of the proteins involved in $\mathrm{TH}$ binding at the plasma membrane allowed for the identification of integrin $\alpha \mathrm{VB3}$ as a binding site $(100,101)$. It was shown that $\mathrm{T} 4$ induces integrin binding to laminin. This interaction activates MAPK and induces actin cytoskeleton remodelling. Since physiological concentrations of T3/T4 can activate MAPK and induce remodelling of actin filaments as well, a link between integrins and THs was hypothesized. In particular, it was suggested that integrin itself is the binding site for T4. Interestingly, T4 covalently linked to agarose is not able to enter the cell, but can still promote MAPK activation (101). A second important finding was made concerning nTRß1. 
Following T4/T3 treatment: i) nTRß1 is rapidly transferred from the cytoplasm to the nucleus in association with MAPK, ii) it is phosphorylated at Ser-142 by MAPK, iii) nTRß1 phosphorylation induces the release of corepressors and the recruitment of coactivators, such as p300, a HAT that also acetylates nTR itself, and finally iv) all of these events can be induced by a physiological concentration of agarose-bound T4 (101). It is also worth mentioning that nTRß1-bound MAPK can phosphorylate other nuclear proteins, such as the oestrogen receptor ER (115) and p53 (116). One general effect of these membrane-dependent $\mathrm{TH}$ actions is the stimulation of the intracellular movement of proteins, which might be related to cytoskeleton remodelling.

Recently, it has been shown that the membrane pathway is also involved in the proliferation-stimulating and anti-apoptotic effects of T4 on papillary and follicular thyroid cancer cell proliferation in vitro (117).

TH-binding proteins have also been found in the cytoplasm. Among these proteins, the reduced nicotinamide adenine dinucleotide phosphate (NADP)-dependent cytosolic T3-binding protein, also known as $\mu$-crystallin (CRYM), seems to play a physiologically fundamental role (118). It might be involved in the regulation of $\mathrm{TH}$ concentration in the extra-nuclear space and, consequently, of the nuclear action of the hormone. From a clinical point of view, CRYM mutations have been found to affect the development of the inner ear (118).

Mitochondrial TH-binding proteins. Mitochondria contain a small genome, the coding capacity of which accounts, in mammals, for 13 proteins that are part of the vital respiratory complexes (reviewed in ref. 119). All the other subunits of the respiratory complexes, as well as the large variety of proteins required for mitochondrial function, are encoded in the nuclear genome, synthesized in the cytoplasm and imported into the organelle by an energy-dependent process. Coordination of the expression of the two genomes relies at least in part on the nuclear respiratory factor-1 (NRF-1), which stimulates the production of the nuclear-encoded transcription factors required for intra-mitochondrial transcription, while enhancing the synthesis of nuclear-encoded respiratory complex subunits (119).

In liver cells, truncated versions of nTRs, TR $\alpha 1$ and RXR have been found to bind mtDNA $(120,121)$. One of the TR $\alpha$ truncated forms (p43) binds to mitochondrial response elements and activates TH-dependent transcription. A smaller isoform (p28) lacks the DNA-binding domain. This protein is imported into the mitochondrial inner membrane in a T3-dependent manner and seems to be involved in the stimulation of oxidative phosphorylation (83). The $\mathrm{p} 43$ protein has also been found in the heart (122), where THs rapidly promote both nuclear and mitochondrial transcription, suggesting that the effects of THs on the mitochondria are, at least in part, not mediated by the nucleus. More recently, the presence of other isoforms of TR $\alpha 1$ and TR $\alpha 2$ in whole mitochondria, mitoplasts and other mitochondrial subfractions has been described (123). As the mitochondrial genome contains nucleotide sequences with high similarity to known hormone-responsive elements, it is likely that the TR isoforms identified in the organelle play an important role in the regulation of mtDNA transcription in response to hormones (124).

\section{Thyroid hormone synthesis, transport and uptake into the brain}

L-thyroxine (T4) and L-triiodothyronine (T3) are both synthesized in the thyroid gland through enzymatic reactions, starting with the iodination of L-tyrosine residues present in thyroglobulin. Thyroglobulin is stored in the gland follicles and, from time to time, is endocyted as colloid droplets and hydrolysed in the lysosomes. Diiodinated and monoiodinated tyrosines are then converted back to tyrosine by deiodination while T4 and T3 are released into circulation, where they bind to carriers for transport to the targets (46). Thyroid-stimulating hormone (TSH) is the principal regulator of TH synthesis and secretion, and also modulates both the proliferation and differentiation of thyroid cells (125).

There are two main carriers for THs in the blood: i) the monomeric thyroxine-binding globulin (TBG), which has the highest affinity for THs and especially for T4 (10-fold higher than it has for T3), and ii) the tetrameric thyroxine-binding prealbumin (TDPA). In addition, albumin can bind T4 in the serum, if only weakly, thus playing an important role in controlling the actual physiological concentration of free THs, the fraction available for interaction with receptors present in the target cells $(46,126)$.

To bind their intracellular receptors, T4 and T3 must enter their target cells. As THs are small hydrophobic molecules, they have been thought to cross the plasma membrane by passive diffusion. However, they also have a polar amino acid side chain that limits their passage and causes their partitioning to the outer half of the lipid bilayer (126). It is now widely accepted that most of their transport across the plasma membrane is mediated by saturable carriers belonging to different families of proteins, which are involved in the transport of a variety of compounds.

The solute carrier proteins are one of the biggest transporter superfamilies. Among them, the organic anion-transporting polypeptides (OATPs) form a family that includes, in humans, 11 members expressed in different tissues including the kidney, liver, intestine, placenta and brain (reviewed in ref. 127). These proteins mediate the $\mathrm{Na}^{+}$-independent transport of many different amphipathic organic compounds: steroid hormones and their catabolic derivatives, bile acids, prostaglandins, and a variety of drugs and xenobiotics. Most OATPs have been shown to be able to bind THs. However, their physiological importance for TH uptake from blood into cells and/or for their efflux into the blood is not yet clear. The class IC of OATPs, which comprehends high-affinity $\mathrm{T} 4$ transporters, seems to be important for TH metabolism (127). Other members probably involved in $\mathrm{TH}$ transport are $1 \mathrm{~A} 2,1 \mathrm{~B} 1,1 \mathrm{~B} 3,3 \mathrm{~A} 1,4 \mathrm{~A} 1$ and 4C1 (127).

THs, as well as rT3 - a naturally-occurring iodothyronine, the concentration of which increases in catabolic states - are able to bidirectionally cross the blood-brain barrier (BBB). Interestingly, rT3 is a competitive inhibitor of TH uptake by several transporter types. This finding could provide a mechanism by which rT3 might negatively regulate $\mathrm{TH}$ actions (126).

Two proteins of the OATP family could be of particular relevance to the brain uptake of THs: i) OATP1A2, a glycoprotein of 670 amino acids that is expressed in brain capillary 
endothelial cells (BCECs) which are responsible for BBB formation (127-129), and ii) OATP1C1, a protein of 712 amino acids expressed in different brain regions and also in BCECs, where it may play a role in the entrance of THs into the brain $(130,131)$.

As the structure of iodothyronines is based on that of thyrosine, amino acid transporters have also been analyzed for TH transport ability. System LI (leucine preferring) permease is an ion-independent carrier for large neutral amino acids, able to transport branched-chain and aromatic amino acids (126). In the early 1970s, it was observed that THs had an effect on amino acid transport in Xenopus laevis embryos (132). Two decades later, it was found that two different L-type amino acid transporter systems (L1 and L2) are present in astrocytes, and that tryptophan transport by $\mathrm{L} 1$, but not by $\mathrm{L} 2$, is competitively inhibited by T3 in cultured astrocytes (133). System L transporters are formed by two subunits: a hydrophobic light chain (the permease) and a regulatory glycoprotein heavy chain. Several different permeases have been cloned; however, only two of them (LAT1 and LAT2) show transport characteristics of System L (126).

Besides System L, a second amino acid transporter has been identified which might be engaged in TH transport. This is System T (tryptophan preferring), an ion-independent transporter for aromatic amino acids (126). Although the role of this system is still under investigation, it seems that both System $\mathrm{L}$ and System T bind T4 and T3, with a preference for T3.

Since LAT1 is the major neutral amino acid transporter expressed at the BBB, System L, in addition to the abovementioned OATP family of carriers, could play a role in TH uptake to the brain. In light of this, a further comment concerning phenylketonuria (PKU) should be made. It has been proposed that an imbalance in the uptake of amino acids to the brain, due to the excess of phenylalanine, contributes to mental retardation in PKU. If, however, amino acid transporters at the BBB are also used to drive THs into the brain, an imbalance in TH delivery should also be considered (126).

Among the membrane transporter systems putatively involved in $\mathrm{TH}$ delivery to the cells is a third group that includes the monocarboxylate transporter 8 (MCT8), first identified in functional assays performed in Xenopus laevis oocytes (134). Immediately after discovery of the MCT8 gene, patients with mutations in MCT8 with a severe neurological syndrome were identified (135-137). The patients manifested hypotonia, dystonic movements, nystagmus and impaired hearing. They also had abnormally high levels of circulating free T3, low levels of free T4 and almost normal levels of TSH in the serum. After mutations in the MTC8 gene of these patients had been identified, the MTC8 gene was also analyzed in patients with Allan-Herndon-Dudley syndrome (AHDS), one of the first X-linked mental retardation syndromes identified. In fact, AHDS patients exhibited many features overlapping those found in patients with MTC8 mutations. All of the AHDS families analyzed had mutations in the MTC8 gene $(137,138)$. The complex pattern of defects in these patients probably depended on two different aspects of TH impairment: i) deficient uptake of T3 to the brain, which should be associated with mental retardation, and ii) abnormally high levels of circulating free T3 (peripheral hyperthyroidism), which could be responsible for toxicity involving the muscle and liver (137).
In humans, expression of MCT8 was indeed demonstrated in the heart, kidney, placenta, liver and, importantly, in the brain (139). In the murine central nervous system (CNS), MCT8 is present in a number of neuronal populations of both the cerebral and cerebellar cortex, hypothalamus, striatum and hippocampus (140). In addition, it is expressed in the choroid plexus (139). Further evidence of the significance of MCT8 in TH transport was based on the analysis of MCT8-deficient mice. Although these animals do not show neurological symptoms comparable to those found in humans, they do show homologous altered serum concentrations of THs (139).

In conclusion, over the last few years different families of membrane transporters have been involved in TH delivery to their targets and, most important, to the brain. These findings suggest that the neurological symptoms associated with hypothyroidism might be the result not only of reduced production and secretion of THs, but also of deficient uptake of THs into the CNS (139-141).

A final important requirement for $\mathrm{TH}$ action on target cells is the conversion of T4 into T3 (the active intracellular hormone) by 5 '-iodothyronine deiodinases 1 and 2 (D1 and D2). In the brain, this reaction is carried out by the D2 enzyme, present primarily in astrocytes $(142,143)$. Notably, the main targets of T3 are neurons. Thus, by locally producing T3, astrocytes might regulate $\mathrm{T} 3$ delivery to nerve cells (125). The catabolism of both T4 and T3 to rT3 and T2, respectively, is finally carried out by the type 3 deiodinase (D3), primarily present in neurons (125).

Fig. 2 shows some putative pathways of entrance into the brain, metabolism and sites of action of THs.

\section{Resistance to thyroid hormones}

In 1967, Refetoff et al described a familial syndrome characterized by deaf-mutism, stippled epiphyses, goiter and abnormally high protein-bound iodine levels, and suggested that the syndrome could depend on target organ refractoriness to THs (144). Since then, many other patients have been described with variable symptoms, including goiter, mental retardation, hearing loss, short stature, tachycardia and dyslexia. The hallmark of the syndrome is a variable degree of resistance to thyroid hormones (RTH), with high levels of circulating THs and TSH and a clinical pattern of mixed hypothyroidism and hyperthyroidism $(1,144-148)$.

After the cloning of the genes encoding nTRs, a link was found between RTH and the TRß gene (149). Since then, a number of different mutations (in most cases, single nucleotide substitutions, but also deletions, frameshift mutations, and mutation-generated stop codons) have been identified in the TRß gene of RTH patients (150-155). The mutations are mainly grouped in the ligand-binding domain of the $\mathrm{nTR} \beta$, and in fact the in vitro translated mutant proteins show a variably reduced ability to bind T3 (145). In most families with RTH, the affected individuals have one normal and one mutated THRB allele, in agreement with the autosomal dominant pattern of RTH inheritance (145). Individuals with a single wt TRß allele (due to deletion of the other allele) are normal. Thus, a single gene for nTRß is enough for TH responsiveness. However, individuals expressing a mutant allele (mnTRß) present RTH because of the so-called 'dominant negative 


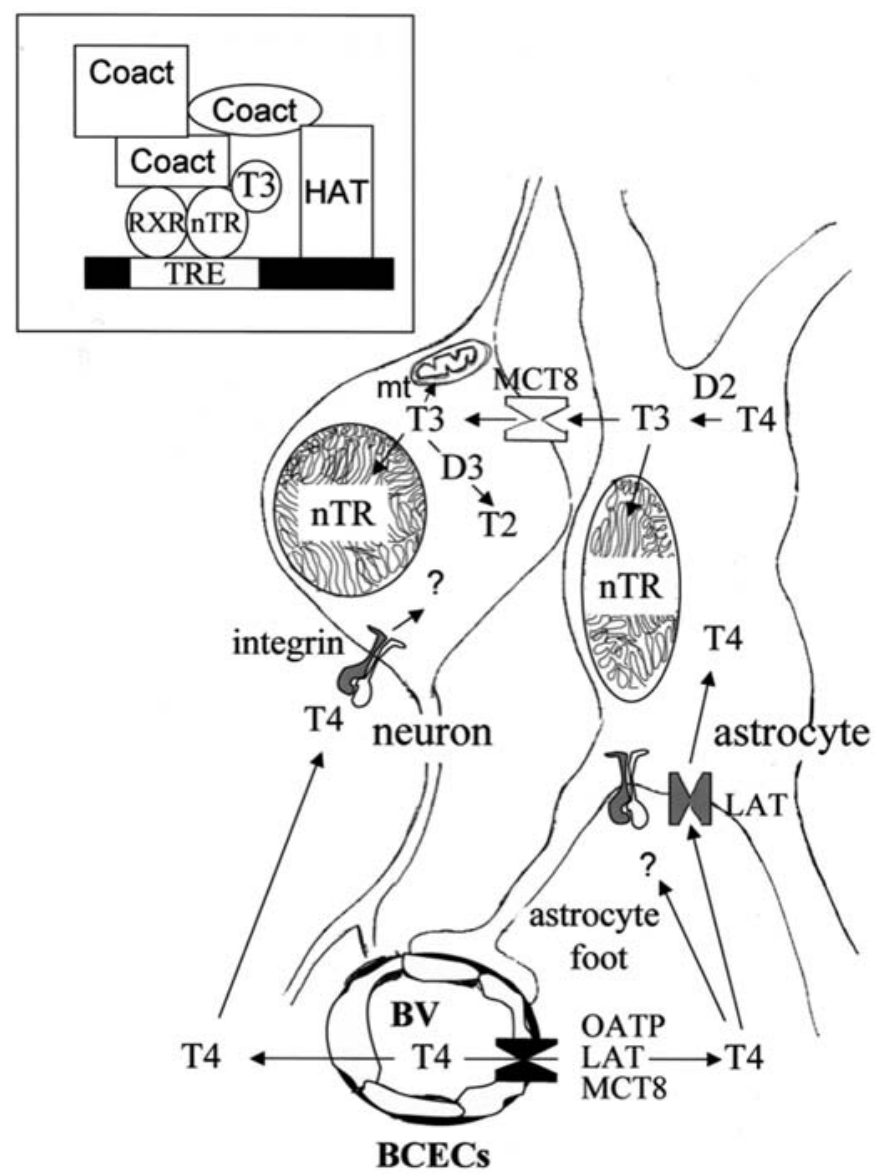

Figure 2. The putative uptake of T4 into brain cells across the blood-brain barrier (BBB) and its metabolism and mode of action in neurons and astrocytes. T4 has been proposed to cross brain capillary endothelial cells (BCECs), which form the walls of blood vessels (BV), via specific transporters, such as the organic anion transporting polypeptides (OATP), the System LI (leucine preferring) permease (LAT) and the monocarboxylate transporter 8 (MCT8). Transporters of the same families have been reported present in astrocytes (LAT) and neurons (MCT8) as well. T4 seems to be able to induce short-term responses in both neurons and astrocytes by binding to membrane receptors (integrins, in at least some cases). Once in the astrocyte, T4 is deiodinated by D2 to produce T3. T3 either enters the nucleus, where it binds to nTRs, or leaves the astrocyte to enter neurons, again to enter the nucleus and bind to nTRs. T3-binding sites have also been reported to be present in mitochondria (mt). As is illustrated, in most cases the nuclear action of T3 depends on the dimerization of nTR with the retinoic acid X receptor (RXR) and on the binding of the dimer to thyroid hormone response elements (TREs) present in the 5'-flanking region of the target genes. Many different coactivators (Coact) bind to the nTR/RXR dimer, thus forming a protein complex that is able to remodel chromatin in order to allow formation of an initiation transcriptional complex. The chromatin remodelling complex possesses histone acetyltransferase (HAT) activity. Question marks indicate intracellular signal transduction pathways that remain to be clearly defined.

effect'. In most cases, the mnTRß is not able to bind T3, but can still bind DNA and presumably dimerize and/or bind coregulators, thus interfering with the functions of the wt nTRß (148).

As mentioned in the previous section, different tissues show different combinations and relative abundances of TRs. As a result, the degree of RTH differs among tissues. Tissues that mainly rely on nTRß (for example, the hypothalamus) show symptoms of hormone deprivation (hypothyroidism), while tissues (such as the heart) that mainly depend on nTR $\alpha$ exhibit signs of hormone excess (hyperthyroidism).
Notably, no germline nTR $\alpha$ mutations have been identified in humans (147).

In order to understand the defects found in RTH and to predict hypothetical phenotypes of $\mathrm{nTR} \alpha$ mutations, animal models have been produced by introducing, into corresponding positions of mouse nTR genes, some of the mutations found in humans. One important initial finding was that both $\alpha$ and $\beta$ nTRs could be deleted without compromising vitality. In contrast, athyreotic mutant mice died prior to weaning. This apparent paradox was attributed to excessive 'negative' signalling by hormone-free nTRs, as confirmed by the fact that removal of the $n T R \alpha$ gene rescued the mutant mouse from death (147). Second, the mutant mice allowed for a correlation to be drawn between nTRß1 deficiency and hearing defects, and between nTRß2 and colour blindness. In addition, TRßKO mice exhibited tachycardia, which normalized after the reduction of $\mathrm{TH}$ levels, suggesting that tachycardia depends on excessive stimulation of $n T R \alpha$. The creation of a mouse model (TRßPV) that carried a mutation discovered in the nTRß of a patient with RTH (156) also allowed for the elucidation of a novel oncogenic activity of the nTRß mutant PV that did not depend on the nuclear activity of nTR $\beta$, but rather involved an ability to physically interact with the regulatory $\mathrm{p} 85 \alpha$ subunit of PI3K in both the nuclear and cytoplasmic compartments (reviewed in refs. 146,157).

Recently, it has been suggested that acquired RTH can be much more frequent than congenital $\mathrm{RTH}$, and that a generally reduced sensitivity to THs in peripheral tissues can occur for different defects involving the various steps through which THs enter the cells and activate a nuclear response $(147,148)$. Such steps, as mentioned in the previous sections, include: i) the secretion and blood delivery of THs, ii) TH transport across the plasma membrane of target cells, iii) the intracellular formation of T3 from T4 by deiodinases, iv) T3 binding to nTRs, and v) the dissociation from nTRs of corepressors and the association of coactivators. It has recently been suggested that a further step might concern $\mathrm{TH}$ transport from the cytoplasm to the nucleus and involve carnitin (reviewed in ref. 148).

In actual fact, the intracellular distribution of nTRs in both the absence and presence of THs appears to be of importance. Yen et al (158) produced a family of green fluorescent fusion proteins containing either wt or mutated nTRß in order to study, by confocal microscopy, their distribution. They found that approximately $90 \%$ of wt nTRß is nuclear both in the presence and absence of T3. Interestingly, this distribution is not altered in mutants that cannot bind the ligand or cannot dimerize. Most important, nuclear localization is not modified in mutants that cannot bind DNA. In contrast, a mutant that cannot bind the N-CoR corepressor shows a predominantly cytoplasmic distribution (158).

Finally, as previously discussed, non-genomic TH effects are also possible.

The existence of all these steps offers, on one hand, a variety of regulatory mechanisms, acting either on the hypothalamus-pituitary-thyroid axis to control TH concentration in the blood, or locally to control actual availability of active hormone at the level of specific target cells. On the other hand, changes at any of the regulatory steps may result in chronic acquired RTH. Since these modifications should affect locally active hormone concentrations, it could be difficult to infer 
non-congenital RTH conditions from blood TH and TSH assays (discussed in ref. 148). Interest in RTH has been roused beause of its peculiar effects on the nervous system. Besides the syndrome described by Refetoff and AHDS, due to MCT8 mutations, other neurological disorders, such as certain forms of depression (159), might be caused by RTH.

\section{Thyroid hormone effects on the nervous system}

The influence of THs on the development and maturation of the mammalian brain, both before and after birth, has been known for over two decades (160). Any impairment in the supply of THs to the developing nervous system leads to severe and irreversible abnormalities of brain structure and function, causing mental retardation in humans (161-166). A particularly TH-sensitive stage of brain development is one at which post-mitotic neurons undertake the outgrowth of axonal and dendritic processes and start establishing and stabilizing the synaptic contacts, while oligodendroglial cells are actively engaged in myelin synthesis. In addition, neurological symptoms are commonly observed in adult patients suffering from hyperthyroidism and hypothyroidism.

Ontogenesis of $T H$ receptors in the brain. The analysis of $\mathrm{nTH}$ ontogenesis has been crucial to inferring the timing of $\mathrm{TH}$ action in the fetal brain. In 1984, Bernal and Pekonen reported that $\mathrm{T} 3$ receptors are present in the human fetal brain from the 10th week of gestation (167). More recently, the mRNas encoding nTR $\alpha 1$ and nTRß1 were detected in human brain samples at as early as 8 weeks of gestation (168). In the rat brain, T3 NRs are found from the 14th day of development. Their expression follows a bimodal pattern of accumulation: an initial increase between the 14th and 16th day of gestation, and a later peak at around the 6th day after birth (169). This pattern of receptor accumulation might reflect two different and successive modes of action of THs on the brain as a whole. Alternatively, it might reflect the emergence of different cell populations sensitive to the hormone at different stages of brain maturation. Indeed, the concentration of T3binding sites is not homogeneous in the various regions of the rat brain, with the density in the pituitary $>$ cerebral hemisphere $>$ brain stem $>$ cerebellum $>$ hypothalamus. Moreover, during the first two weeks of postnatal development, nuclear binding capacity changes differently in the cerebral hemispheres, brain stem and cerebellum (170). In general, in both the mammalian and non-mammalian vertebrate brain, nTRß mRNA was found to be expressed later in development, while nTR $\alpha$ mRNA was expressed at earlier stages $(26,171,172)$. In the chick, differential expression of $n T R \alpha$ and $\beta$ mRNAs is particularly evident in the cerebellum, where, by in situ hybridization, the nTRß mRNA concentration was found to increase in white matter and granule cells after the migratory phase, while nTR $\alpha$ mRNA was expressed in the earlier proliferating and migrating granule cells and in the more mature granular and Purkinje cell layers after hatching. Both nTRs are already expressed at even earlier phases, such as embryonal day 9, with nTR 3 mRNA restricted to the ventricular epithelium of the metencephalon and nTR $\alpha$ mRNA expressed in migrating cells and the early granular layer (173). On the other hand, Strait et al (174) found, by immunohistochemistry, that the rat cerebellum contains significant amounts of nTRß1, mostly present in the nuclei of Purkinje cells, in spite of low nTRß1 mRNA levels. They also observed high levels of nTR $\alpha 2$ in the nuclei of granule cells (174). Independent and somehow complementary expression of $\alpha$ and $\beta$ isotypes of nTRs was also found in other regions of the rat brain, such as the cerebral cortex and hippocampus, suggesting that the different isotypes play different roles during brain development, as well as in the adult brain $(175,176)$. More recently, as expected, specific roles of the nTR isotypes have been argued on the basis of defects shown by knockin mutant mice (58). However, the specific roles of nTR isoforms in brain development have yet to be clarified, and one of the most critical challenges for the future is to understand how local cellular context may modulate the isoform-dependent effects of THs.

TH effects on the developing brain. Most TH effects on the developing brain have been studied in the rat, where it has been inferred that THs do not affect early neural developmental processes (i.e. neural induction, neurulation and establishment of polarity and segmentation), but instead influence later events in brain development and maturation, such as cell migration, cortical layer formation, proliferation and the differentiation of specific neuronal and glial cell populations and synaptogenesis (125). As mentioned, fetal and/or maternal hypothyroidism in this critical phase results in severe abnormalities in cell migration and connectivity, as well as in the overall cortical layer architecture $(31,125,177)$. In the cerebellum, hypothyroidism delays the proliferation and migration of granule cells; the precursors of these cells originate from the edge of the 4th ventricle and, after migrating to the external germinal layer of the cerebellum, continue to proliferate for a while. They then begin migrating inward to the internal granular layer, along the radially-oriented processes of the Bergmann glial cells, and differentiate on their way (125). In hypothyroid animals, all these processes are severely delayed. However, the delay can be reversed if THs are administered within 2 weeks of birth (1). Purkinje cells of the cerebellum, together with the pyramidal neurons of the cerebral cortex and hippocampus, are among the neuronal classes most affected by hypothyroidism, causing a lower number and an abnormal distribution of dendritic spines and synaptic connections (125). These classes of cells have also been found to express significantly lower amounts of nTR isoforms in human fetuses with intrauterine growth restriction, the major cause of perinatal mortality and morbidity, associated with reduced circulating free T4 and T3 (178).

Since T3 effects are mainly mediated by nTRs, a large body of work has been devoted to the search for T3 target genes in the CNS. In Purkinje cells, for example, at least three genes have been found to be regulated by THs: the Purkinje cell protein 2 (Pcp-2), calbindin, and the inositol-trisphosphate (IP3) receptor (27). Interestingly, the Pcp-2 gene promoter contains, in addition to two TREs that mediate gene activation during the second and third weeks of rat postnatal life, a 'T3 response silencing element' that mediates the repression of T3-dependent gene activation in the fetal and neonatal rat brain (179). This element binds other nuclear factors not present/active in the T3-responsive brain, suggesting that the presence or absence of repressor proteins may contribute to 
establishing the precise timing of expression of T3-responsive genes (179).

Another group of T3-responsive genes expressed in the brain are those encoding neurotrophins: nerve growth factor, neurotrophin-3 (NT-3), and brain-derived neurotrophic factor (180-182). Recently, it has been suggested that nTR action on these genes can be enhanced by the retinoic acid receptorrelated orphan receptor $\alpha(\operatorname{ROR} \alpha)$; in the mutant mouse staggerer (sg), which has a deletion in the ROR $\alpha$ gene and which shows aberrant cerebellar development, the expression of various neurotrophins is down-regulated, probably as a consequence of the failure of the mutant RORsg to enhance nTR activity (183).

T3 dependence has also been described in genes encoding cytoskeletal proteins, such as different tubulin isotypes (184-186), actin (186) and various isoforms of microtubuleassociated proteins $(185,187)$. Regulation of the expression of these proteins is often complex, indicating transcriptional as well as post-transcriptional components. For example, Lorenzo et al (188) found that the effects of $\mathrm{T} 3$ on the T $\alpha 1$ tubulin gene promoter are indirect, and that the hormone also affects the half-life of the T $\alpha 1$ tubulin mRNA. Similarly, it was found that $\mathrm{T} 3$ regulates the splicing of juvenile and adult $\tau$ mRNAs (189). However, the regulation of $\tau$ mRNA splicing probably depends on the transcriptional regulation of the musashi-1 (msi-1) gene, which encodes an RNA-binding protein induced by $\mathrm{T} 3$ during rat brain development and in N2a cells (190). T3 increases the msi-1 mRNA level in an actinomycin D-sensitive, cycloheximide-resistant fashion without affecting its half-life, which suggests a transcriptional effect (190). The HuD gene, which encodes another neuronspecific, RNA-binding protein that modulates mRNA stability, is also regulated by T3 (191). HuD expression is strongly upregulated in specific areas of the hypothyroid rat brain, and is down-regulated by $\mathrm{T} 3$ in rat PC12 and mouse N2a cells. Furthermore, T3 inhibited the transcription of $\mathrm{HuD}$ in run-on assays (191). Since HuD protein binds with high affinity to acetylcholinesterase mRNA, it was suggested that HuD mediates certain $\mathrm{T} 3$ effects by altering the half-life of mRNAs for acetylcholinesterase and other genes (191).

TH-responsive genes are, among others, those encoding RC3/neurogranin (192), rhes (a Ras-homolog small GTPase enriched in the striatum) (193), N-CAM (194), nTRß (195), M1 muscarinic acetylcholine receptor (196), GAP-43 $(196,197)$, glucose transporters 1 and 3 (GLUT1 and GLUT3) (198) and the synaptosomal-associated protein of $25 \mathrm{kDa}$ (SNAP-25) (199). Moreover, THs affect the synthesis of SRC-1 and the nuclear corepressor NCoR (200).

Four additional TH-responsive genes have been identified in rat brain neuronal cultures: basic transcription elementbinding protein, nuclear pore glycoprotein P62, bone morphogenetic protein-4 and the neuronal apoptosis-inducing gene (DPS). The first three genes are up-regulated and the last one down-regulated by T3 (201). Moreover, by comparing the gene expression profiles of control newborn mice at the 4th postnatal day (P4) with age-matched experimentally hypothyroid mice and hypothyroid mice treated with tiroxine, Takahashi et al (202) identified six novel TH-responsive genes expressed in the developing cerebellum: orc11, galr3, sort1, nlgn3, cdk5r2 and zfp367. Three of these genes (sort1, cdk5r2 and zfp367) were immediately up-regulated by a single injection of tiroxine in hypothyroid as well as control animals (202).

Besides neurons, glial cells are also highly sensitive to THs during differentation.

During the 1970s, it was discovered that, in hypothyroid rats, the number of oligodendrocytes was reduced (203-206) and that, after the induction of experimental hypothyroidism, neonatal rats at P15-P40 showed much less CNS myelin than did age-matched controls $(204,207,208)$. On the other hand, hyperthyroid rats showed a higher accumulation of myelin at P13 (204). Curiously, as development progressed, the mature composition of myelin was reached in both cases, although in hyperthyroid rats the myelin yield was $20 \%$ less than it was in the euthyroid rats (discussed in ref. 209).

It is known that, after the critical period of $\mathrm{TH}$ action on the development of the CNS (the first two weeks after birth in rats), the expression of many genes altered by perinatal hypothyroidism eventually reaches the same levels as in euthyroid animals - in spite of morphological abnormalities in brain structures $(125,179,209,210)$.

Oligodendrocytes (OLs) are derived from oligondendrocyte progenitor cells (OPCs), also called oligodendrocyte type-2 astrocyte (O-2A) progenitors (reviewed in ref. 209). OPCs can be induced to divide by different mitogens, the most important of these being platelet-derived growth factor (PDGF-AA) both in vivo and in vitro $(211,212)$. Their growth arrest is probably under the control of an intrinsic timing mechanism (206), not yet understood. However, since in other cell systems the decay of positive regulators, such as cyclins and cyclin-dependent kinases (Cdks), and the accumulation of negative regulators, such as Cdk inhibitors p21 and p27, have been shown to induce withdrawal from the cell cycle, a possible role of these proteins in OPC differentiation has been investigated (209). An increase in p27 has been found to be part of the mechanism leading to OL differentiation. Notably, the increase in p27 in OPCs is paralleled by an increase in the levels of nTRß (213). Moreover, retroviral vector-driven ectopic expression of nTRß in fibroblasts causes a dramatic arrest in proliferation, accompanied by changes in the main cell cycle regulators involved in the G1-S transition. This finding suggests that nTRß controls OPC proliferation inhibition in a ligand-independent way (209). Moreover, the expression of nTRs helps maturing OPCs to respond to TH and start terminal differentiation $(206,209)$. In addition, it has been reported that T3 is a survival factor for developing oligodendrocytes (214). T3 is also important for OL maturation, as the hormone regulates the expression of many genes involved in myelination, such as those encoding myelin basic protein (MBP), proteolipid protein (PLP) and myelin-associated glycoprotein (MAG). The first two genes are, at least in part, regulated at the transcriptional level, while MAG regulation is mostly post-transcriptional (reviewed in refs. 209,215).

One of the differences between normal and hypothyroid rat cerebellum at postnatal day 4 is the lack of differentiated astrocytes in the internal granular layer (216). Moreover, the normal developmental pattern of expression by astrocytes of intermediate filament proteins is altered in hypothyroid rats; the vimentin-glial fibrillary acidic protein (GFAP) transition is delayed and most differentiated astrocytes remain in the white matter (216). As astrocytes contain both $\alpha$ and $\beta$ isotypes 
of nTRs, they are probably direct targets of THs. Notably, it was also noticed that THs had an effect on GFAP phosphorylation and cytoskeletal organization, which seemed to be mediated by a pathway involving the RhoA small GTPase and to depend directly on T4 (217).

Similarly, it was recently reported that both T4 and rT3, but not $\mathrm{T} 3$, directly regulate the F-actin content of elongating neurites of cerebellar neurons in culture through a non-genomic mechanism. In turn, modulation of the actin cytoskeleton has a profound influence on the ability of neurons to migrate from the explants onto a laminin substrate and to emit neurites. These effects are blocked by synthetic peptides that compete with the RGD (arginine-glycine-aspartic acid) integrin recognition sequence, and by antibodies directed against $\beta 1$ integrin (218). A further event that seems to be non-genomic in brain cells in culture is the regulation by THs of type II 5'-deiodinase (D2) $(219,220)$. Moreover, T4 and rT3 (but not T3) have been reported to have, in vivo, the effects on D2 activity and actin polymerization already observed in brain cultures (104). These findings suggest that THs may influence brain maturation through additional mechanisms, independent of regulated gene expression (see section 3, 'General mechanisms of thyroid hormone action'). In agreement with this finding, it had already been reported that laminin and THs had synergistic effects on the polarity of rat cortical neurons in culture. In more detail, it was observed that the addition of T3 to the medium of differentiating neurons, cultured on laminin, had no effect on the average concentration of different cytoskeletal proteins, such as the neurofilament $68-\mathrm{kDa}$ component (NF-68) or the microtubule-associated protein 2 (MAP-2). T3, however, seemed to be critical for the sub-cellular localization of these proteins (221).

Several years ago, we observed that T3 in rat cortical neurons in culture can induce the structural reorganization of chromatin that characterizes the terminal differentiation of cortical neurons in vivo $(222,223)$. This chromatin structural reorganization was probably linked to the synthesis and incorporation of differentiation-specific histone replacement variants, such as the linker histone $\mathrm{H} 1^{\circ}$ and the core histone H3.3 (224). The expression of the two histone variants was found to be regulated mostly at the post-transcriptional level (224). Since post-transcriptional regulation very often relies on regulatory RNA-binding proteins (reviewed in ref. 225), we looked for proteins able to bind histone mRNAs. In the course of this search, we identified a cold shock-domain (CSD)containing protein that seemed able to bind $\mathrm{H} 1^{\circ}$ and $\mathrm{H} 3.3$ mRNAs (226-228) and was present both in the nucleus and the cytoplasm of brain cells (227). As other CSD-containing proteins have the ability to interact with both RNA and chromatin, we investigated the possibility that PIPPin binds to chromatin. We also looked for effects had by T3 on PIPPin expression by comparing newborn euthyroid rats with newborns delivered by rats treated with 6-propyl-2-thiouracyl (PTU) during the last week of pregnancy. In parallel, we analyzed rat cortical neurons cultured in a chemically-defined medium (Maat Medium: 229) with or without T3, and found a significant difference between newborn euthyroid and hypothyroid rats concerning the sumoylation of nuclear PIPPin, which was abolished by hypothyroidism (230). In addition, we showed that a higher proportion of nuclear PIPPin localized to the nuclear periphery in T3-treated cells than in control neurons. As specific localization of nuclear proteins has been often reported to require post-translational modifications, such as ubiquitination or sumoylation, we suggested that intranuclear localization of at least one fraction of PIPPin depends on TH-dependent sumoylation (230).

As a final comment on genes regulated by THs during brain development, it is worth mentioning that the genes responsible for $\mathrm{TH}$ action, such as those encoding nTRs and deiodinases, are also TH-responsive. For example, the activity of mammalian type II iodothyronine deiodinase (D2) increases in the brain of hypothyroid animals (231). Thus, it is probably part of a feedback loop that contributes to maintaining T3 concentration in the brain (232). On the other hand, D3, which inactivates both $\mathrm{T} 3$ and $\mathrm{T} 4$, is induced by $\mathrm{T} 3$ and decreases in the hypothyroid brain (233). These observations suggest that the coordinated expression of D2 and D3 is critical for TH homeostasis in the developing CNS (209). However, it was recently found that D2 knockout mice (D2KO) show neurological defects much milder than those observed in hypothyroid animals. Moreover, the levels of mRNAs encoded by T3-responsive genes are unaffected or only slightly affected in $\mathrm{D} 2 \mathrm{KO}$. On the basis of these findings, it has been proposed that other significant compensatory mechanisms must be at work to minimize functional abnormalities in the absence of D2 (234).

THs and the adult brain: examples of putative TH-dependent neurological disorders. Although the effects of TH deficiency on CNS development have been well established, much less is known concerning its influence on the adult brain where, in contrast, $\alpha 1, \alpha 2$ and $\beta 1$ isotypes of nTRs are widely expressed (172). Adult hypothyroidism does not cause the severe structural defects found in developmental hypothyroidism. However, a TH deficit in adulthood is associated with impairment in learning, verbal fluency, spatial tasks $(235,236)$ and affective homeostasis (237), as well as in some psychiatric illnesses (238). The fact that adult hypothyroid rats have cognitive deficits and depression suggests that the brain areas involved in learning/memory and mood control, such as the hippocampus, are altered (239). Desouza et al (240) indeed found that adult-onset hypothyroidism significantly decreases hippocampal neurogenesis. The main reason for this deficit seems to be a significant decrease in the survival and differentiation of the progenitor cells (240).

The relationship between THs and affective disorders is complex and bidirectional. For example, thyroid diseases can induce psychiatric disorders that, in turn, may be responsible for thyroid diseases $(241,242)$.

One such common psychiatric condition is bipolar disorder (manic-depressive illness), characterized by cyclic episodes of mania and depression. This condition is successfully treated with lithium, although the molecular basis of its effect is still unknown. Since lithium has been shown to regulate a number of different genes in the rat brain and cultured cells, it has been proposed that its mood-stabilizing activity depends on the regulation of gene expression (243). Among the lithiumregulated genes are those encoding nTRs (244), and it was recently found that short-term $\mathrm{LiCl}$-treatment modifies the relative concentrations of nTRs in an isoform-specific manner 
(i.e. $n T R \alpha 1$ increases, $n T R \alpha 2$ decreases and nTRß1 is unaffected), and affects the cytoplasmic availability of thyroxine in the adult rat brain (245). Diazepam (also known as valium or stedon), one of the most widely used tranquillizers, has also been reported by the same authors to affect the nTR expression levels in the adult rat brain (246). In contrast, adjuvant T3 treatment accelerates the effects of antidepressants in some patients $(247,248)$, and T4 has been used in the therapy of depression. Interestingly, it has been recently suggested that chronic T4 treatment induces a significant increase in the 5-HT2A serotonin receptor in the mouse brain (249).

Multiple sclerosis (MS) is an inflammatory, demyelinating disease of the CNS that ends up causing lesions of the myelin sheath and axonal damage. In theory, since a significant number of OPCs are present in the CNS, repair of the lesions should be possible. However, remyelination is morphologically and functionally abnormal (250). The reason for remyelination failure is not clear, especially when considering that new oligodendrocytes are spontaneously generated in the course of MS. Since myelination during development is regulated, as discussed previously, by THs, the possibility has been explored of promoting myelination in chronic experimental allergic encephalomyelitis (EAE), a widely used experimental model of MS, by treating the animals with THs (reviewed in ref. 251). The results of this study suggest that the clinical course of the EAE animals was positively affected by $\mathrm{TH}$. In the course of treatment, up-regulation of the genes encoding myelin components, as well as of the genes encoding neurotrophins, was observed (251).

A final example of the possible involvement of THs in adult CNS disorders concerns neuroserpin, a serine protease inhibitor with a putative role in the regulation of anxiety. Some neuroserpin mutations cause alterations in protein conformation, resulting in the aggregation and formation of inclusion bodies in CNS neurons (252). Neuroserpin mRNA contains an AU-rich element in the 3'-untranslated region, recognized and bound by the previously mentioned RNAbinding protein $\mathrm{HuD}$ (191), which acts as an mRNA stabilizer. Neuroserpin mRNA is down-regulated in various regions of the hypothyroid brain, including cortical layers II/III and VIa, and the hippocampus, but not elsewhere, such as cortical layer V (253). THs do not affect the transcription of the neuroserpin gene, but do induce the stabilization of its mRNA, probably via an increase in HuD levels (253).

\section{Conclusions}

THs have profound effects on the nervous system. As discussed, severe TH deficiency during pregnancy results in cretinism, while mild hypothyroidism is associated with insufficient cognitive development. Moreover, TH fluctuations in adulthood are associated with mood alterations, and the adult brain metabolism probably adapts to maintain $\mathrm{TH}$ homeostasis. Although it has been known since the 1980s that most of the effects had by THs are mediated by NRs, in the last decade there has been increasing interest in the molecular mechanisms that mediate rapid $\mathrm{TH}$ action, probably involving plasma membrane receptors. In addition, membrane transporters seem to regulate $\mathrm{TH}$ access to the brain. Even more interest has recently been aroused regarding THs and their effects on the CNS, and in the future the challenge will be to understand how the different pathways of $\mathrm{TH}$ action interact in order to drive the development of the CNS and to contribute to the homeostasis and the correct functioning of the adult brain.

\section{Acknowledgements}

I wish to thank Carlo M. Di Liegro, Gabriella Schiera and Patrizia Proia for critically reviewing the manuscript.

\section{References}

1. Yen PM: Physiological and molecular basis of thyroid hormone action. Physiol Rev 81: 1097-1142, 2001

2. Kendall EC: The isolation in crystalline form of the compound containing iodine which occurs in the thyroid: its chemical nature and physiological activity. Trans Assoc Am Physicians 30: 420-449, 1915.

3. Gross J and Pitt-Rivers R: Triiodothyronine in relation to thyroid physiology. Recent Prog Horm Res 10: 109-128, 1954.

4. Tata JR, Ernster L, Lindberg O, Arrhenius ESP and Hedman R: The action of thyroid hormones at the cell level. Biochem $\mathrm{J} 86$ : 408-428, 1963.

5. Tata JR and Widnell CC: Ribonucleic acid synthesis during the early action of thyroid hormones. Biochem J 98: 604-629, 1966.

6. Oppenheimer JK, Koerner D, Scwartz HL and Surks MI: Specific nuclear triiodothyronine binding sites in rat liver and kidney. $\mathrm{J}$ Clin Endocrinol Metab 73: 330-333, 1972.

7. Samuels HH and Tsaj JS: Thyroid hormone action in cell culture: demonstration of nuclear receptors in intact cells and isolated nuclei. Proc Natl Acad Sci USA 70: 3488-3492, 1973.

8. Oppenheimer JK, Scwartz HL and Surks MI: Tissue differences in the concentration of triiodothyronine nuclear binding sites in the rat: liver, kidney, pituitary, heart, brain, spleen, and testis. Endocrinology 95: 897-903, 1974.

9. Pascual AS, Casanova J and Samuels HH: Photoaffinity labelling of thyroid hormone receptors in intact cells. J Biol Chem 257: 9640-9647, 1982.

10. Dozin B, Cahnmann HJ and Nikodem VM: Identification of thyroid hormone receptors in rat liver nuclei by photoaffinity labelling with L-thyroxine and triiodothyronine. Biochemistry 24: 5197-5202, 1985.

11. Magnuson MA, Dozin B and Nikodem VM: Regulation of specific rat liver messenger ribonucleic acids by triiodo-thyronine. J Biol Chem 260: 5906-5912, 1985.

12. Crew CD and Spindler SR: Thyroid hormone regulation of the transfected rat growth hormone promoter activity. J Biol Chem 261: 5018-5022, 1986.

13. Izumo S, Nadal-Ginard B and Mahdavi V: All the members of the MHC multigene family respond to thyroid hormone in a highly tissue-specific manner. Science 231: 597-600, 1986.

14. Larsen PR, Harney JW and Moore DD: Sequences required for cell-specific thyroid hormone regulation of rat growth hormone promoter activity. J Biol Chem 261: 14733-14736, 1986.

15. Lavin TN, Baxter JD and Horita S: The thyroid hormone receptor binds to multiple domains of the rat growth hormone 5'-flanking sequence. J Biol Chem 263: 9418-9426, 1988.

16. Samuels HH, Forman BM, Horowitz ZD and Ye S: Regulation of gene expression by thyroid hormones. J Clin Invest 81: 957-967, 1988 .

17. Hollenberg SM, Weinberger C and Ong ES: Primary structure and expression of a functional glucocorticoid receptor cDNA. Nature 318: 635-641, 1885.

18. Green S, Walter P, Kumar V, Krust A, Bornert JM, Argos P and Chambon P: Human oestrogen receptor cDNA: sequence, expression and homology to v-erb-A. Nature 320: 134-139, 1986.

19. Weinberger C, Thompson CC, Ong ES, Lebo R, Gruol DJ and Evans RM: The c-erbA gene encodes a thyroid hormone receptor. Nature 324: 641-646, 1986

20. Sap J, Munoz A, Damm K, Goldberg Y, Ghysdael J, Leutz A, Beug $\mathrm{H}$ and Vennstrom $\mathrm{B}$ : The c-erbA protein is a high affinity receptor for thyroid hormone. Nature 324: 635-640, 1986.

21. Izumo $S$ and Mahadavi V: Thyroid hormone receptor $\alpha$ isoforms generated by alternative splicing differentially activate myosin HC gene transcription. Nature 334: 539-542, 1988. 
22. Lazar MA, Hodin RA, Darling DS and Chin WW: Identification of a rat c-erbA $\alpha$-related protein which binds deoxyribonucleic acid and does not bind thyroid hormone. Mol Endocrinol 2: 893-901, 1988.

23. Lazar MA, Hodin RA, Darling DS and Chin WW: A novel member of the thyroid/steroid hormone receptor family is encoded by the opposite strand of the rat c-erbA $\alpha$ transcriptional unit. Mol Cell Biol 9: 1128-1136, 1989.

24. Mitsuhashi TG, Tennyson GE and Nikodem VM: Alternative splicing generates messages encoding rat c-erbA proteins that do not bind thyroid hormone. Proc Natl Acad Sci USA 85: 684-693, 1988.

25. Cook CB and Koenig RJ: Expression of erbA alpha and beta mRNAs in regions of adult rat brain. Mol Cell Endocrinol 70: 13-20, 1990.

26. Castiglia D, Cestelli A, Di Liegro C, Bonfanti L and Di Liegro I: Accumulation of different c-erbA transcripts during rat brain development and in cortical neurons cultured in a synthetic medium. Cell Mol Neurobiol 12: 259-272, 1992.

27. Strait KA, Zou L and Oppenheimer JH: Beta 1 isoform-specific regulation of a triiodothyronine-induced gene during cerebellar development. Mol Endocrinol 6: 1874-1880, 1992.

28. Weiss RM and Noback CR: The effect of thyroxine and thiouracil on the time of appearance of ossification centers of rat fetuses. Endocrinology 45: 389-395, 1949.

29. Morreale de Escobar G, Pastor R, Obregon MJ and Escobar del Rey F: Effects of maternal hypothyroidism on the weight and thyroid hormone content of rat embryonic tissues, before and after onset of fetal thyroid function. Endocrinology 117: 1890-1900, 1985.

30. Bianco AC, Salvatore D, Gereben B, Berry MJ and Larsen PR: Biochemistry, cellular and molecular biology, and physiological roles of the iodothyronine selenodeiodinases. Endocr Rev 23: 38-89, 2002.

31. Morreale de Escobar G, Obregon MJ and Escobar del Rey F: Maternal thyroid hormones early in pregnancy and fetal brain development. Best Pract Res Clin Endocrinol Metab 18: 225-248, 2004.

32. Huang SA, Dorfman DM, Genest DR, Salvatore D and Larsen PR: Type 3 iodothyronine deiodinase is highly expressed in the human uteroplacental unit and in fetal epithelium. J Clin Endocrinol Metab 88: 1384-1388, 2003.

33. Gray B and Galton VA: The transplacental passage of thyroxine and foetal thyroid function in the rat. Acta Endocrinol 75: 725-733, 1974.

34. Sweney LR and Shapiro BL: Thyroxine and palatal development in the rat. Dev Biol 42: 19-27, 1975.

35. Porterfield SP and Hendrich CE: The effects of growth hormone treatment of thyroid-deficient pregnant rats on maternal and fetal carbohydrate metabolism. Endocrinology 99: 786-792, 1976.

36. Man EB and Serunian SA: Thyroid function in human pregnancy. IX. Development or retardation of 7-year-old progeny of hypothyroxinemic women. Am J Obstet Gynecol 125: 949, 1976.

37. Obregon MJ, Mallol J, Pastor R, Morreale del Escobar G and Escobar del Rey F: Thyroxine and 3,5,5'-triiodothyronine in rat embryos before onset of fetal thyroid function. Endocrinology 114: 305-307, 1984.

38. Woods RJ, Sinha AK and Ekins R: Uptake and metabolism of thyroid hormones by the rat foetus in early pregnancy. Clin Sci 67: 359-363, 1984.

39. Escobar del Rey F, Pastor R, Mallol J and Morreale de Escobar G: Effects of maternal iodide deficiency on the L-thyroxine and 3,5,3'-triiodo-L-thyronine contents of rat embryonic tissues before and after onset of fetal thyroid function. Endocrinology 118: $1259-1265,1986$

40. Ruiz de Oña C, Obregon MJ, Escobar del Rey F and Morreale de Escobar G: Developmental changes in rat brain 5'-deiodinase and thyroid hormones during the fetal period: the effects of fetal hypothyroidism and maternal thyroid hormones. Pediatr Res 24 : 588-594, 1988.

41. James SR, Franklin JA and Kilby MD: Placental transport of thyroid hormone. Best Pract Res Clin Endocrinol Metab 21: 253-264, 2007.

42. Calvo RM, Jauniaux E, Gulbis B, Asunción M, Gervy C, Contempré B and Morreale de Escobar G: Fetal tissues are exposed to biologically relevant free thyroxine concentrations during early phases of development. J Clin Endocrinol Metab 87: 1768-1777, 2002.
43. Koopdonk-Kool JM, De Vijlder JJ, Veenboer GJ, Ris-Stalpers C, Kok JH, Vulsma T, Boer K and Visser TJ: Type II and type III deiodinase activity in human placenta as a function of gestation age. J Clin Endocrinol Metab 81: 2154-2158, 1996.

44. Santini F, Chiovato L, Ghirri P, Lapi P, Mammoli C, Montanelli L, Scartabelli G, Ceccarini G, Coccoli L, Chopra IJ, Boldrini A and Pichera A: Serum iodothyronines in the human fetus and the newborn: evidence for an important role of placenta in fetal thyroid hormone homeostasis. J Clin Endocrinol Metab 84: 493-498, 1999.

45. Chan S, Kachilele S, Hobbs E, Bulmer JN, Boelaert K, McCabe CJ, Driver PM, Bradwell AR, Kester M, Visser TJ, Franklyn JA and Kilby MD: Placental iodothyronine deiodinase expression in normal and growth-restricted human pregnancies. J Clin Endocrinol Metab 88: 4488-4495, 2003.

46. Di Liegro I, Savettieri G and Cestelli A: Cellular mechanism of action of thyroid hormones. Differentiation 35: 165-175, 1987.

47. Bernal J and De Groot LJ: Mode of action of thyroid hormone. In: The Thyroid Gland. De Visscher M (ed). Raven Press, New York, pp123-143, 1980 .

48. Kolodny JM, Larsen PR and Silva JE: In vitro 3,5,3'-triiodothyronine binding to rat cerebrocortical neuronal and glial nuclei suggests the presence of binding sites unavailable in vivo. Endocrinology 116: 2019-2028, 1985.

49. Margarity M, Matsokis $\mathrm{N}$ and Valcana T: Characterization of nuclear triiodothyronine (T3) and tetraiodothyronine (T4) binding in developing brain tissue. Mol Cell Endocrinol 31: 333-351, 1983.

50. Oppenheimer JH: Thyroid hormone action at the cellular level. Science 203: 971-979, 1979.

51. Aranda A and Pascual A: Nuclear hormone receptors and gene expression. Physiol Rev 81: 1269-1304, 2001.

52. Zhang $\mathrm{J}$ and Lazar MA: The mechanism of action of thyroid hormones. Annu Rev Physiol 62: 439-466, 2000.

53. Wu Y and Koenig RJ: Gene regulation by thyroid hormones. Trends Endocrinol Metab 11: 207-211, 2000.

54. McKenna NJ and O'Malley BW: Combinatorial control of gene expression by nuclear receptors and coregulators. Cell 108: 465-474, 2002.

55. Nevado J, Tenbaum SP and Aranda A: hSrb7, an essential human mediator component, acts as a coactivator for thyroid hormone receptor. Mol Cell Endocrinol 222: 41-51, 2004.

56. Katz RW, Subauste JS and Koenig RJ: The interplay of half-site sequence and spacing on the activity of direct repeat TH response elements. J Biol Chem 270: 5238-5242, 1995.

57. Cheng S-Y: Multiple mechanisms for regulation of the transcriptional activity of thyroid hormone receptors. Rev Endocr Metab Disord 1: 9-18, 2000.

58. Cheng S-Y: Isoform-dependent action of thyroid hormone nuclear receptors: lessons from knockin mutant mice. Steroids 70: 450-454, 2005.

59. Wahlstrom GM, Sjoberg M, Andersson M, Nordström K and Vennström B: Binding characteristic of the TH receptor homoand heterodimers to consensus AGGTCA repeat motifs. Mol Endocrinol 6: 1013-1022, 1992.

60. Zechel C, Shen XQ, Chen JY, Chen ZP, Chambon P and Gronemeyer $\mathrm{H}$ : The dimerization interfaces formed between the DNA binding domains of RXR, RAR and TR determine the binding specificity and polarity of the full-length receptors to direct repeats. EMBO J 13: 1425-1433, 1994.

61. Desvergne B: How do thyroid hormone receptors bind to structurally diverse response elements? Mol Cell Endocrinol 100: 125-131, 1994.

62. Wu Y, Xu B and Koenig RJ: Thyroid hormone response element sequence and the recruitment of retinoid $\mathrm{X}$ receptors for thyroid hormone responsiveness. J Biol Chem 276: 3929-3936, 2001.

63. Velasco LF, Togashi M, Walfish PG, Pessanha RP, Moura FN, Barra GB, Nguyen P, Rebong R, Yuan C, Simeoni LA, Ribeiro RC, Baxter JD, Webb P and Neves FA: Thyroid hormone element organization dictates the composition of active receptor. J Biol Chem 282: 12458-12466, 2007.

64. Nascimento AS, Gomes Dias SM, Nunes FM, Aparício R, Ambrosio ALB, Bleicher L, Figueira ACM, Santos MAM, De Oliveira Neto M, Fischer H, Togashi M, Craievich AF, Garratt RC, Baxter JD, Webb P and Polikarpov I: Structural rearrangements in the thyroid hormone receptor hinge domain and their putative role in the receptor function. J Mol Biol 360: 586-598, 2006.

65. Mengeling BJ, Lee S and Privalsky ML: Coactivator recruitment is enhanced by thyroid hormone receptor trimers. Mol Cell Endocrinol 280: 47-62, 2008. 
66. Hyyti OM and Portman MA: Molecular mechanisms of cross-talk between thyroid hormone and peroxisome proliferator activated receptors: focus on the heart. Cardiovasc Drugs Ther 20: 463-469, 2006.

67. Weisbrod S: Active chromatin. Nature 297: 289-295, 1982.

68. Weintraub H: Assembly and propagation of repressed and suppressed chromosomal states. Cell 42: 705-711, 1985.

69. Nyborg JK and Spindler SR: Alterations in local chromatin structure accompany thyroid hormone induction of growth hormone gene transcription. J Biol Chem 261: 5685-5688, 1986.

70. Usala SJ, Young WS III, Morioka H and Nikodem VM: The effect of thyroid hormone on the chromatin structure and expression of the malic enzyme in hepatocytes. Mol Endocrinol 2: 619-626, 1988.

71. Williams GR and Brent GA: Thyroid hormone response elements. In: Molecular Endocrinology: Basic Concepts and Clinical Correlations. Weintraub B (ed). Raven Press, New York, pp217-239, 1995 .

72. Feng X, Yuan J, Meltzer PB and Yen PM: TH regulation of hepatic genes in vivo detected by cDNA microarray. Mol Endocrinol 14: 947-955, 2000.

73. Flores-Morales A, Gullberg H, Fernandez L, Ståhlberg N, Lee NH, Vennström B and Norstedt G: Pattern of liver gene expression governed by TRbeta. Mol Endocrinol 16: 1257-1268, 2002.

74. Smith CL and O'Malley BW: Coregulator function: a key to understanding tissue specificity of selective receptor modulators. Endrocr Rev 25: 45-71, 2004.

75. Spiegelman BM and Heinrich R: Biological control through regulated transcriptional coactivators. Cell 119: 157-167, 2004.

76. Rosenfeld MG, Lunyak VV and Glass CK: Sensors and signals: a coactivator/corepressor/epigenetic code for integrating signaldependent programs of transcriptional response. Genes Dev 20: 1405-1428, 2006.

77. Feige JN and Auwerx J: Transcriptional coregulators in the control of energy homeostasis. Trends Cell Biol 17: 292-301, 2007.

78. Méndez-Pertuz M, Sánchez-Pacheco A and Aranda A: The thyroid hormone receptor antagonizes CREB-mediated transcription. EMBO J 22: 3102-3112, 2003.

79. García-Silva S and Aranda A: The thyroid hormone receptor is a suppressor of ras-mediated transcription, proliferation, and transformation. Mol Cell Biol 24: 7514-7523, 2004.

80. Perez-Juste G and Aranda A: The cyclin-dependent kinase inhibitor p27 (kip1) is involved in thyroid hormone-mediated neuronal differentiation. J Biol Chem 274: 5026-5031, 1999.

81. Ogryzko VV, Schiltz RL, Russanova V, Howard BH and Nakatani Y: The transcriptional coactivators $\mathrm{p} 300$ and CBP are histone acetyltransferases. Cell 87: 953-959, 1996.

82. Spencer TE, Jenster G, Burcin MM, Allis CD, Zhou J, Mizzen CA, McKenna NJ, Onate SA, Tsai SY, Tsai MJ and O'Malley BW: Steroid receptor coactivator-1 is a histone acetyltransferase. Nature 389: 194-198, 1997.

83. Oetting A and Yen PM: New insights into thyroid hormone action. Best Pract Res Clin Endocrinol Metab 21: 193-208, 2007.

84. Li D, Desai-Yajnik V, Lo E, Schapira M, Abagyan R and Samuels HH: NRIF3 is a novel coactivator mediating functional specificity of nuclear hormone receptors. Mol Cell Biol 19: 7191-7202, 1999

85. Horlein AJ, Näär AM, Heinzel T, Torchia J, Gloss B, Kurokawa R, Ryan A, Kamei Y, Söderström M, Glass CK and Rosenfeld MG: Ligand-independent repression by the thyroid hormone receptor mediated by a nuclear receptor co-repressor. Nature 377: 397-404, 1995.

86. Chen JD and Evans RM: A transcriptional co-repressor that interacts with nuclear hormone receptors. Nature 377: 454-457, 1995.

87. Jepsen K, Hermanson O, Onami TM, Gleiberman AS, Lunyak V, McEvilly RJ, Kurokawa R, Kumar V, Liu F, Seto E, Hedrick SM, Mandel G, Glass CK, Rose DW and Rosenfeld MG: Combinatorial roles of the nuclear receptor corepressors in transcription and development. Cell 102: 753-763, 2000.

88. Hermanson O, Jepsen K and Rosenfeld MG: N-CoR controls differentiation of neural stem cells into astrocytes. Nature 419: 934-939, 2002.

89. Malartre M, Short S and Sharpe C: Xenopus embryos lacking specific isoforms of the corepressor SMRT develop abnormal heads. Dev Biol 292: 333-343, 2006.

90. Gurevich I, Flores AM and Aneskievich BJ: Corepressors of agonist-bound nuclear receptors. Toxicol Appl Pharmacol 223: 288-298, 2007.
91. Koenig RJ, Lazar MA, Hodin RA, Brent GA, Larsen PR, Chin WW and Moore DD: Inhibition of TH action by a nonhormone binding c-erbA protein generated by alternative mRNA splicing. Nature 337: 659-661, 1989.

92. Katz D, Berrodin TJ and Lazar MA: The unique C-termini of the $\mathrm{TH}$-receptor variant, $\mathrm{c}$-erbAa2, and $\mathrm{TH}$ receptor a1 mediate different DNA-binding and heterodimerization properties. Mol Endocrinol 6: 805-814, 1992.

93. Nagaya $\mathrm{T}$ and Jameson JL: Distinct dimerization domains provide antagonist pathways for TH receptor action. J Biol Chem 268: 24278-24282, 1993.

94. Tagami T, Kopp P, Johnson W, Arseven OK and Jameson JL: The thyroid hormone receptor variant apha2 is a weak antagonist because it is deficient in interactions with nuclear receptor corepressors. Endocrinology 139: 2535-2544, 1998.

95. Miyajima N, Horiuchi R, Shibuya Y, Fukushige S, Matsubara K, Toyoshima K and Yamamoto T: Two erbA homologs encoding proteins with different T3 binding capacities are transcribed from opposite DNA strands of the same genetic locus. Cell 57: 31-39, 1989.

96. Spanjaard RA, Nguyen VP and Chin WW: Rat Rev-erbA alpha, an orphan receptor related to $\mathrm{TH}$ receptor, binds to specific $\mathrm{TH}$ response elements. Mol Endocrinol 8: 286-295, 1994.

97. Segal J: In vivo effect of 3,5,3'-triiodothyronine on calcium uptake in several tissues in the rat: evidence for a physiological role of calcium as a first messenger for the prompt action of thyroid hormone at the level of the plasma membrane. Endocrinology 127: 17-24, 1990

98. Kavok NS, Krasilnikova OA and Babenko NA: Thyroxine signal transduction in liver cells involves phospholipase $\mathrm{C}$ and phospholipase D activation. Genomic independent action of thyroid hormone. BMC Cell Biol 2: 5-12, 2001.

99. D'Arezzo S, Incerpi S, Davis FB, Filippo A, Marino M, Farias RN and Davis PJ: Rapid nongenomic effects of 3,5,3'-triiodo-Lthyronine on the intracellular $\mathrm{pH}$ of L-6 myoblasts are mediated by intracellular calcium mobilization and kinase pathways. Endocrinology 145: 5694-5703, 2004.

100. Bergh JJ, Lin HY, Lansing L, Mohamed NS, Davis FB, Moura S and Davis JP: Integrin $\alpha \mathrm{VB3}$ contains a cell surface receptor site for thyroid hormone that is linked to activation of MAPK and induction of angiogenesis. Endocrinology 146: 2864-2871, 2005.

101.Davis PJ, Davis FB and Cody V: Membrane receptors mediating thyroid hormone action. Trends Endocrinol Metab 16: 429-435, 2005.

102. Incerpi S, Scapin S, D'Arezzo S, Spagnuolo S and Leoni S: Short term effects of thyroid hormone in prenatal development and cell differentiation. Steroids 70: 434-443, 2005

103. Menegaz D, Zamoner A, Royer C, Leite LD, Bartolotto ZA and Silva FR: Rapid responses to thyroxine in the testis: active protein synthesis-independent pathway. Mol Cell Endocrinol 246: 128-134, 2006.

104. Farwell AP, Dubord-Tomasetti SA, Pietrzykowski AZ and Leonard JL: Dynamic nongenomic actions of thyroid hormone in the developing rat brain. Endocrinology 147: 2567-2574, 2006.

105. Moeller LC, Cao X, Dumitrescu AM, Seo H and Refetoff S: Thyroid hormone mediated changes in gene expression can be initiated by cytosolic action of the thyroid hormone receptor $\beta$ through the phosphatidylinositol 3-kinase pathway. Nucl Recept Signal 4: 1-4, 2006

106.Zamoner A, Royer C, Padilha Barreto K, Pessoa-Pureur R and Mena Barreto Silva FR: Ionic involvement and kinase activity on the mechanism of nongenomic action of thyroid hormones on ${ }^{45} \mathrm{Ca}^{2+}$ uptake in cerebral cortex from young rats. Neurosci Res 57: 98-103, 2007

107. Goldfine ID, Simons CG, Smith GH and Ingbar SH: Cycloleucine transport in isolated rat thymocytes: in vitro effects of triiodothyronine and thyroxine. Endocrinology 96: 1030-1038, 1975.

108. Pliam NB and Goldfine ID: High affinity thyroid hormone binding sites on purified rat liver plasma membranes. Biochem Biophys Res Commun 79: 166-172, 1977.

109. Segal J and Gordin A: The effects of actinomycin D, puromycin, cycloheximide and hydroxyurea on 3,5,3'-triiodo-L-thyronine stimulated 2-deoxy-D-glucose uptake in chick embryo heart cells in vitro. Endocrinology 101: 150-156, 1977.

110. Segal J and Ingbar SH: Stimulation by triiodothyronine of the in vitro uptake of sugars by rat thymocytes. J Clin Invest 63 : 507-512, 1979

111. Botta JA, Mendoza D, Morero RD and Farias RN: High affinity L-triiodothyronine binding sites on washed rat erythrocyte membranes. J Biol Chem 258: 6690-6692, 1983. 
112. Stanley F, Tsai JS and Samuels HH: Stimulation of facilitated $\left[{ }^{3} \mathrm{H}\right]$-uridine transport by thyroid hormone in GH1 cells. J Biol Chem 261: 9000-9004, 1986.

113. Incerpi S, De Vito P, Luly P, Spagnuolo S and Leoni S: Shortterm effects of thyroid hormones and 3,5-diiodothyronine on membrane transport systems in chick embryo hepatocytes. Endocrinology 143: 1660-1668, 2002.

114. Storey NM, Gentile S, Ullah H, Russo A, Muessel M, Exleben C and Armstrong DL: Rapid signalling at the plasma membrane by a nuclear receptor for thyroid hormone. Proc Natl Acad Sci USA 103: 5197-5201, 2006.

115. Tang HY, Lin HY, Zhang S, Davis FB and Davis PJ: Thyroid hormone causes mitogen-activated protein kinase-dependent phosphorylation of the nuclear estrogen receptor. Endocrinology 145: 3265-3272, 2004.

116. Shih A, Lin HY, Davis FB and Davis PJ: Thyroid hormone promotes serine phosphorylation of $\mathrm{p} 53$ by mitogen-activated protein kinase. Biochemistry 40: 2870-2878, 2001.

117.Lin H-Y, Tang H-Y, Shih A, Keating T, Cao G, Davis PJ and Davis FB: Thyroid hormone is a MAPK-dependent growth factor for thyroid cancer cells and is anti-apoptotic. Steroids 72: 180-187, 2007.

118. Suzuki S, Mori J-I and Hashizume K: $\mu$-crystallin, a NADPHdependent T3-binding protein in cytosol. Trends Endocrinol Metab 18: 286-289, 2007.

119. Cannino G, Di Liegro CM and Rinaldi AM: Nuclearmitochondrial interaction. Mitochondrion 7: 359-366, 2007.

120. Casas F, Rochard P, Rodier A, Cassar-Malek I, MarchalVictorion S, Wiesner RJ, Cabello G and Wrutniak C: A variant form of the nuclear triiodothyronine receptor c-ErbAalpha1 plays a direct role in regulation of mitochondrial RNA synthesis. Mol Cell Biol 19: 7913-7924, 1999.

121. Casas F, Daury L, Grandemange S, Busson M, Seyer P, Hatier R, Carazo A, Cabello G and Wrutniak-Cabello C: Endocrine regulation of mitochondrial activity: involvement of a truncated RXRalpha and c-ErbAalpha1 proteins. Fed Am Soc Exp Biol J 17: 426-436, 2003.

122. Goldenthal MJ, Ananthakrishnan R and Marin-Garcia J: Nuclear-mitochondrial cross-talk in cardiomyocyte T3 signaling: a time-course analysis. J Mol Cell Cardiol 39: 319-326, 2005.

123. Morrish F, Buroker NE, Ge M, Ning X-H, Lopez-Guisa J, Hockenbery D and Portman MA: Thyroid hormone receptor isoforms localize to cardiac mitochondrial matrix with potential for binding to receptor elements on mtDNA. Mitochondrion 6: $143-148,2006$

124. Psarra AM, Solakidi S and Sekeris CE: The mitochondrion as a primary site of action of steroid and thyroid hormones: presence and action of steroid and thyroid hormone receptors in mitochondria of animal cells. Mol Cell Endocrinol 246: 21-33, 2006.

125. Santisteban P and Bernal J: Thyroid development and effect on the nervous system. Rev Endocr Metab Disord 6: 217-228, 2005.

126. Taylor PM and Ritchie JWA: Tissue uptake of thyroid hormone by amino acid transporters. Best Pract Res Clin Endocrinol Metab 21: $237-251,2007$

127. Hagenbuch B: Cellular entry of thyroid hormones by organic anion transporting polypeptides. Best Pract Res Clin Endocrinol Metab 21: 209-221, 2007

128. Gao B, Hagenbuch B, Kullak-Ublick GA, Benke D, Aguzzi A and Meier PJ: Organic anion-transporting polypeptides mediate transport of opioid peptides across blood-brain barrier. J Pharmacol Exp Ther 294: 73-79, 2000

129. Lee W, Glaeser H, Smith LH, Roberts RL, Moeckel GW, Gervasini G, Leake BF and Kim RB: Polymorphisms in human organic anion-transporting polypeptide 1A2 (OATP1A2): implications for altered drug disposition and central nervous system drug entry. J Biol Chem 280: 9610-9617, 2005.

130. Sugiyama D, Kusuhara H, Taniguchi H, Ishikawa S, Nozaki Y Aburatani $\mathrm{H}$ and Sugiyama Y: Functional characterization of rat brain-specific organic anion transporter (Oatp14) at the blood-brain barrier: high affinity transporter for thyroxine. J Biol Chem 278: 43489-43495, 2003.

131. Tohyama K, Kusuhara $\mathrm{H}$ and Sugiyama Y: Involvement of multispecific organic anion transporter, Oatp14 (Slc21a14), in the transport of thyroxine across the blood-brain barrier. Endocrinology 145: 4384-4391, 2004.

132. Robinson D, Prahlad KV and Hampel AE: Amino acid uptake by Xenopus laevis embryos: effect of triiodo-L-thyronine. Comp Biochem Physiol 43: 749-754, 1972.
133. Blondeau JP, Beslin A, Chantoux F and Francon J: Triiodothyronine is a high-affinity inhibitor of amino acid transport system L1 in cultured astrocytes. J Neurochem 60: 1407-1413, 1993.

134. Friesema EC, Ganguly S, Abdalla A, Manning Fox JE, Halestrap AP and Visser TJ: Identification of monocarboxylate transporter 8 as a specific thyroid hormone transporter. J Biol Chem 278: 40126-40135, 2003.

135. Dumitrescu AM, Liao XH, Best TB, Brockmann K and Refetoff S: A novel syndrome combining thyroid and neurological abnormalities is associated with mutations in a monocarboxylate transporter gene. Am J Hum Genet 74: 168-175, 2004.

136. Friesema EC, Grueters A, Biebermann H, Krude H, von Moers A, Reeser M, Barrett TG, Mancilla EE, Svensson J, Kester MH, Kuiper GG, Balkassmi S, Uitterlinden AG, Koehrle J, Rodien P, Halestrap AP and Visser TJ: Association between mutations in a thyroid hormone transporter and severe X-linked psychomotor retardation. Lancet 364: 1435-1437, 2004.

137. Schwartz CE and Stevenson RE: The MCT8 thyroid hormone transporter and Allan-Herndon-Dudley syndrome. Best Pract Res Clin Endocrinol Metab 21: 307-321, 2007.

138. Schwartz CE, May MM, Carpenter NJ Rogers RC, Martin J, Bialer MG, Ward J, Sanabria J, Marsa S, Lewis JA, Echeverri R, Lubs HA, Voeller K, Simensen RJ and Stevenson RE: AllanHerndon-Dudley syndrome and the monocarboxylate transporter 8 (MCT8) gene. Am J Hum Genet 77: 41-53, 2005.

139. Heuer H: The importance of thyroid hormone transporters for brain development and function. Best Pract Res Clin Endocrinol Metab 21: 265-276, 2007.

140. Heuer H, Maier MK, Iden S, Mittag J, Friesema EC, Visser TJ and Bauer K: The monocarboxylate transporter 8 linked to human psychomotor retardation is highly expressed in thyroid hormonesensitive neuron populations. Endocrinology 146: 1701-1706, 2005.

141. Suzuki T and Abe T: Thyroid hormone transporters in the brain. Cerebellum 13: 1-9, 2007

142. Bates JM, St. Germain DL and Galton VA: Expression profiles of the three iodothyronine deiodinases D1, D2 and D3, in the developing rat. Endocrinology 140: 844-851, 1999.

143. Guadaño-Ferraz A, Obregon MJ, St. Germain DL and Bernal J: The type 2 iodothyronine deiodinase is expressed primarily in glial cells in the neonatal rat brain. Proc Natl Acad Sci USA 94: 10391-10396, 1997.

144. Refetoff S, De Wind LT and De Groot LJ: Familial syndrome combining deaf-mutism, stippled epiphyses, goiter and abnormally high PBI: possible target organ refractoriness to thyroid hormones. J Clin Endocrinol Metab 27: 279-294, 1967.

145. Yen PM: Molecular basis of resistance to thyroid hormone. Trends Endocrinol Metab 14: 327-333, 2003

146. Cheng S-Y: Thyroid hormone receptor mutations and disease: beyond thyroid hormone resistance. Trends Endocrinol Metab 16: 176-182, 2005

147. Refetoff S and Dumitrescu AM: Syndromes of reduced sensitivity to thyroid hormone: genetic defects in hormone receptors, cells transporters and deiodination. Best Pract Res Clin Endocrinol Metab 21: 277-305, 2007.

148. Tjorve E, Tjorve KMC, Olsen JO, Senum R and Oftebro H: On commonness and rarity of thyroid hormone resistance: a discussion based on mechanisms of reduced sensitivity in peripheral tissues. Med Hypotheses 69: 913-921, 2007.

149. Usala SJ, Bale AE, Gesundheit N, Weinberger C, Lash RW, Wondisford FE, McBride OW and Weintraub BD: Tight linkage between the syndrome of generalized thyroid hormone resistance and the human c-erb $\beta$ gene. Mol Endocrinol 2: 1217-1220, 1988

150. Sakurai A, Takeda K, Ain K, Ceccarelli P, Nakai A, Seino S, Bell GI, Refetoff S and De Groot LJ: Generalized resistance to thyroid hormones associated with a mutation in the ligandbinding domain of the human thyroid hormone receptor $\mathrm{b}$. Proc Natl Acad Sci USA 86: 8977-8981, 1989.

151. Usala SJ, Tennyson GE, Bale AE, Lask RW, Gesudheit N, Wondisford FE, Accili D, Hauser P and Weintraub BD: A base mutation of the cerbAb thyroid hormone receptor in a kindred with generalized thyroid hormone resistance. Molecular heterogeneity in two other kindreds. J Clin Invest 85: 93-100, 1990.

152. Behr M and Loos U: A point mutation (Ala229 to Thr) in the hinge domain of the c-erbA beta thyroid hormone receptor gene in a family with generalized thyroid hormone resistance. Mol Endocrinol 6: 1119-1126, 1992. 
153. Beck-Peccoz P and Chatterjee VK: The variable clinical phenotype in thyroid hormone resistance syndrome. Thyroid 4: 225-232, 1994

154. Onigata K, Yagi H, Sakurai A, Nagashima T, Nomura Y, Nagashima K, Hashzume K and Morikawa A: A novel point mutation (R243Q) in exon 7 of the c-erbA beta thyroid hormone receptor gene in a family with resistance to thyroid hormone. Thyroid 5: 355-358, 1995 .

155. Collingwood TN, Wagner R, Matthews $\mathrm{CH}$, Clifton-Bligh RJ, Gurnell M, Rajanayagam O, Agostini M, Fletterick RJ, Beck-Peccoz P, Reinhardt W, Binder G, Ranke MB, Hermus A, Hesch RD, Lazarus J, Newrick P, Parfitt V, Raggatt P, De Zegher F and Chatterjee VK: A role for helix 3 of the TRbeta ligandbinding domain in coactivator recruitment identified by characterization of a third cluster of mutations in resistance to thyroid hormone. EMBO J 17: 4760-4770, 1998.

156. Kaneshige M, Kaneshige K, Zhu X, Dace A, Garrett L, Carter TA, Kazlauskaite R, Pankratz DG, Wynshaw-Boris A, Refetoff S, Weintraub B, Willingham MC, Barlow $\mathrm{C}$ and Cheng S: Mice with a targeted mutation in the thyroid hormone beta receptor gene exhibit impaired growth and resistance to thyroid hormone. Proc Natl Acad Sci USA 97: 13209-13214, 2000.

157. Furuya F, Ying H, Zhao L and Cheng S-Y: Novel functions of thyroid hormone receptor mutants: beyond nucleus-initiated transcription. Steroids 72: 171-179, 2007.

158. Yen PM, Ando S, Feng X, Liu Y, Maruvada P and Xia X: Thyroid hormone action at the cellular, genomic and target gene levels. Mol Cell Endocrinol 246: 121-127, 2006.

159. Fardella CE, Artigas RA, Gloger S, Jiménes M, Carvajal CA, Krall PM, Quiroz D, Campino C and Mosso LM: Refractory depression in a patient with peripheral resistance to thyroid hormone $(\mathrm{RTH})$ and the effect of triiodothyronine treatment. Endocrine 31: 272-278, 2007.

160. Legrand J: Thyroid hormone effects on growth and development. In: Thyroid Hormone Metabolism. Henneman G (ed). M Dekker Inc, New York, pp503-534, 1986.

161. Pharoah PO, Buttfield IH and Hetzel BS: Neurological damage to fetus resulting from severe iodine deficiency during pregnancy. Lancet 1: 308-310, 1971.

162. DeLong GR, Stanbury JB and Fierro-Benitez A: Neurological signs in congenital iodine deficiency disorders. Dev Med Child Neurol 27: 317-324, 1985.

163. Stein SA, Adams PM, Shanklin DR, Mihailoff GA and Palnitkar MB: Thyroid hormone control of brain and motor development: molecular, neuroanatomical, and behavioural studies. Adv Exp Med Biol 299: 47-105, 1991.

164. Heyerdahl S: Intellectual development in children with congenital hypothyroidism in relation to T4 replacement. J Pedriatr 118: 850-855, 1991.

165. Haddow JE, Palomaski GE, Allan WC, Williams JR, Knight GJ, Gagnon J, O'Heir CE, Mitchell ML, Hermos RL, Waisbren SE, Faix JD and Klein RZ: Maternal thyroid deficiency during pregnancy and subsequent neuropsychological development of the child. N Engl J Med 341: 549-555, 1999.

166.Pop VJ, Kuijpens JL and van Baar AL: Low maternal free thyroxine concentrations during early pregnancy are associated with impaired psycomotor development in infancy. Clin Endocrinol 50: 149-155, 1999.

167. Bernal J and Pekonen F: Ontogenesis of the nuclear 3,5,3'triiodothyronine receptor in the human fetal brain. Endocrinology 114: 677-684, 1984.

168. Iskaros J, Pickard M, Evans I, Sinha A, Ardiman P and Ekins R: Thyroid hormone receptor gene expression in first trimester human fetal brain. J Clin Endocrinol Metab 85: 2620-2623, 2000.

169.Perez-Castillo A, Bernal J, Ferreiro B and Pans T: The early ontogenesis of thyroid hormone receptor in the rat fetus Endocrinology 117: 2457-2461, 1985

170. Valcana T: The role of triiodothyronine (T3) receptors in brain development. In: Neural Growth and Differentiation. Meisani E and Brazier MAB (eds). Raven Press, New York, pp39-59, 1979.

171. Forrest D, Sjöberg M and Vennström B: Contrasting developmental and tissue-specific expression of $\alpha$ and $\beta$ thyroid hormone receptor genes. EMBO J 9: 1519-1528, 1990.

172. Strait KA, Schwartz HL, Perez-Castillo A and Oppenheimer JM: Relationship of c-erbA content to tissue triiodothyronine nuclear binding capacity and function in developing and adult rats. J Biol Chem 265: 10514-10521, 1990.
173. Forrest D, Hallböök F, Persson H and Vennström B: Distinct functions for thyroid hormone receptors $\alpha$ and $B$ in brain development indicated by differential expression of receptor genes. EMBO J 10: 269-275, 1991.

174. Strait KA, Schwartz HL, Seybold VS, Ling NC and Oppenheimer JH: Immunofluorescence localization of thyroid hormone receptor beta 1 and variant alpha 2 in selected tissues: cerebellar Purkinje cells as a model for beta 1 receptor-mediated developmental effects of thyroid hormone in brain. Proc Natl Acad Sci USA 88: 3887-3891, 1991.

175. Mellstrom B, Naranjo JR, Santos A, Gonzales AM and Bernal J: Independent expression of the alpha and beta c-erbA genes in developing rat brain. Mol Endocrinol 5: 1339-1350, 1991

176. Bradley DJ, Towle HC and Young WS III: Spatial and temporal expression of alpha- and beta-thyroid hormone receptor mRNAs, including the beta-2-subtype, in the developing mammalian nervous system. J Neurosci 12: 2288-2302, 1992.

177. Auso E, Lavado-Autric R, Cuevas E, Del Rey FE, Morreale de Escobar $\mathrm{G}$ and Berbel P: A moderate and transient deficiency of maternal thyroid function at the beginning of fetal neocorticogenesis alters neuronal migration. Endocrinology 145: 4037-4047, 2004.

178. Kilby MD, Gittoes N, McCabe C, Verhaeg J and Franklyn JA: Expression of thyroid receptor isoforms in the human fetal central nervous system and the effects of intrauterine growth restriction. Clin Endocrinol 53: 469-477, 2000.

179. Anderson GW, Hagen SG, Larson RJ, Strait KA, Schwartz HL, Mariash $\mathrm{CN}$ and Oppenheimer JH: Purkinje cell protein-2 ciselements mediate repression of T3-dependent transcriptional activation. Mol Cell Endocrinol 131: 79-87, 1997

180. Giordano T, Pan JB, Casuto D, Watanabe S and Arneric SP. Thyroid hormone regulation of NGF, NT-3 and BDNF RNA in the adult rat brain. Brain Res Mol Brain Res 16: 239-245, 1992.

181. Koibuchi N, Fukuda H and Chin WW: Promoter-specific regulation of the brain derived neurotrophic factor gene by thyroid hormone in the developing rat cerebellum. Endocrinology 140: 3955-3961, 1999

182. Koibuchi N, Yamaoka S and Chin WW: Effect of altered thyroid status on neurotrophin gene expression during post-natal development of the mouse cerebellum. Thyroid 11:205-210, 2001.

183. Qiu CH, Shimokawa N, Iwasaki T, Parhar IS and Koibuchi N: Alteration of cerebellar neurotrophin messenger ribonucleic acids and the lack of thyroid hormone receptor augmentation by staggered-type retinoic acid receptor-related orphan receptoralpha mutation. Endocrinology 148: 1745-1753, 2007.

184. Aniello F, Couchie D, Gripois D and Nunez J: Regulation of five tubulin isotypes by thyroid hormone during brain development. J Neurochem 57: 1781-1786, 1991.

185. Nunez J, Couchie D, Aniello F and Bridoux AM: Regulation by thyroid hormone of microtubule assembly and neuronal differentiation. Neurochem Res 16: 975-982, 1991

186. Poddar R, Paul S, Chaudhury S and Sarkar PK: Regulation of actin and tubulin gene expression by thyroid hormone during rat brain development. Brain Res Mol Brain Res 35: 111-118, 1996.

187. Benjamin S, Cambray-Deakin MA and Burgoyne RD: Effect of hypothyroidism on the expression of three microtubule-associated proteins (1A, 1B and 2) in developing rat cerebellum. Neuroscience 27: 931-939, 1988.

188. Lorenzo PI, Ménard C, Miller FD and Bernal J: Thyroid hormone-dependent regulation of $\mathrm{T} \alpha 1 \alpha$-tubulin during brain development. Mol Cell Neurosci 19: 333-343, 2002.

189. Aniello F, Couchie D, Bridoux AM, Gripois D and Nunez J: Splicing of juvenile and adult tau mRNA variants is regulated by thyroid hormones. Proc Natl Acad Sci USA 88: 4035-4039, 1991.

190. Cuadrado A, García-Fernández LF, Imai T, Okano H and Muñoz A: Regulation of tau RNA maturation by thyroid hormone is mediated by the neural RNA-binding protein musashi-1. Mol Cell Neurosci 20: 198-210, 2002.

191. Cuadrado A, Navarro-Yubero C, Furneaux H and Muñoz A Neuronal HuD gene encoding a mRNA stability regulator is transcriptionally repressed by thyroid hormone. J Neurochem 86: 763-773, 2003

192. Morte B, Iñiguez MA, Lorenzo PI and Bernal J: Thyroid hormone-regulated expression of $\mathrm{RC} 3 /$ neurogranin in the immortalized hypothalamic cell line GT1-7. J Neurochem 69: 902-909, 1997.

193. Vargiu P, Morte B, Manzano J, Perez J, De Abajo R, Gregor Sutcliffe J and Bernal J: Thyroid hormone regulation of rhes, a novel Ras homolog gene expressed in the striatum. Brain Res Mol Brain Res 94: 1-8, 2001. 
194.Iglesias T, Caubín J, Stunnenberg HG, Zaballos A, Bernal J and Muñoz A: Thyroid hormone-dependent transcriptional repression of neural cell adhesion molecule during brain maturation. EMBO J 15: 4307-4316, 1996.

195.Lebel JM, L'Hérault S, Dussault JH and Puymirat J: Thyroid hormone up-regulates thyroid hormone receptor beta gene expression in rat cerebral hemisphere astrocyte cultures. Glia 9: 105-112, 1993

196. Kobayashi K, Tsuji R, Yoshioka T, Kushida M, Yabushita S, Sasaki M, Mino T and Seki T: Effects of hypothyroidism induced by perinatal exposure to PTU on rat behavior and synaptic gene expression. Toxicology 212: 135-147, 2005.

197. Muñoz A, Rodriguez-Peña A, Perez-Castillo A, Ferreiro B, Sutcliffe JG and Bernal J: Effects of neonatal hypothyroidism on rat brain gene expression. Mol Endocrinol 5: 273-280, 1991.

198. Santalucía T, Palacín M and Zorzano A: T3 strongly regulates GLUT1 and GLUT3 mRNA in cerebral cortex of hypothyroid rat neonates. Mol Cell Endocrinol 251: 9-16, 2006.

199.Zhang H-M, Su Q and Luo M: Thyroid hormone regulates the expression of SNAP-25 during rat brain development. Mol Cell Biochem 307: 169-175, 2008.

200.Iannacone EA, Yan AW, Gauger KJ, Dowling ALS and Zoeller RT: Thyroid hormone exerts site-specific effects on SRC-1 and NCoR expression selectively in the neonatal rat brain. Mol Cell Endocrinol 186: 49-59, 2002.

201. Martel J, Cayrou C and Puymirat J: Identification of new thyroid hormone-regulated genes in rat brain neuronal cultures. Neuroreport 13: 1849-1851, 2002.

202. Takahashi M, Negishi T and Tashiro T: Identification of genes mediating thyroid hormone action in the developing mouse cerebellum. J Neurochem: Nov. 14, 2007 (Epub ahead of print).

203. Bass NH and Young E: Effects of hypothyroidism on the differentiation of neurons and glia in developing rat cerebrum. J Neurol Sci 18: 155-173, 1973 .

204. Walters SN and Morell P: Effects of altered thyroid states on myelinogenesis. J Neurochem 36: 1792-1801, 1981.

205. Clos J, Legrand J, Limozin N, Dalmasso C and Laurent G: Effects of abnormal thyroid state and undernutrition on carbonic anhydrase and oligodendroglia development in the rat cerebellum. Dev Neurosci 5: 243-251, 1982.

206. Ibarrola N, Mayer-Proschel M, Rodriguez-Peña A and Noble M: Evidence for the existence of at least two timing mechanisms that contribute to oligodendrocyte generation in vitro. Dev Biol 180: 1-21, 1996.

207. Matthieu J-M, Reier PJ and Sawchak JA: Proteins of rat brain myelin in neonatal hypothyroidism. Brain Res 84: 443-451, 1975.

208. Valcana T, Einstein ER, Csejtey J, Dalal KB and Timiras PS: Influence of thyroid hormones on myelin proteins in the developing rat brain. J Neurol Sci 25: 19-27, 1975.

209. Sarliève LL, Rodriguez-Peña A and Langley K: Expression of thyroid hormone receptor isoforms in the oligodendrocyte lineage. Neurochem Res 29: 903-922, 2004.

210. Koibuchi N, Jingu H, Iwasaki T and Chin WW: Current perspectives on the role of thyroid hormone in growth and development of cerebellum. Cerebellum 2: 279-289, 2003.

211. Raff MC, Lillien LE, Richardson WD, Burne JF and Noble MD: Platelet-derived growth factor fron astrocytes drives the clock that times oligodendrocyte development in culture. Nature 333: 562-565, 1998 .

212. Calver AR, Hall AC, Yu WP, Walsh FS, Heath JK, Betsholtz C and Richardson WD: Oligodendrocyte population dynamics and the role of PDGF in vivo. Neuron 20: 869-882, 1998.

213. Gao F-B, Apperly J and Raff M: Cell-intrinsic timers and thyroid hormone regulate the probability of cell cycle withdrawal and differentiation of oligodendrocyte precursor cells. Dev Biol 197: 54-66, 1998.

214. Jones SA, Jolson DM, Cuta KK, Mariash CN and Anderson GW: Triiodothyronine is a survival factors for developing oligodendrocytes. Mol Cell Endocrinol 199: 49-60, 2003.

215. Rodriguez-Peña A: Oligodendrocyte development and thyroid hormone. J Neurobiol 40: 497-512, 1999.

216. Manzano J, Bernal J and Morte B: Influence of thyroid hormones on maturation of rat cerebellar astrocytes. Int $\mathrm{J}$ Dev Neurosci 25: 171-179, 2007.

217.Zamoner A, Funchal C, Jacques-Silva MC, Gottfried C, Silva FR and Pessoa-Pureur R: Thyroid hormones reorganize the cytoskeleton of glial cells through gfap phosphorylation and rhoa-dependent mechanisms. Cell Mol Neurobiol 27: 845-865, 2007.
218. Farwell AP, Dubord-Tomasetti SA, Pietrzykowski AZ, Stachelek SJ and Leonard JL: Regulation of cerebellar neuronal migration and neurite outgrowth by thyroxine and 3,3',5'triiodothyronine. Brain Res Dev Brain Res 154: 121-135, 2005.

219. Silva JE and Leonard JL: Regulation of rat cerebrocortical and adenohypophyseal type II 5'-deiodinase by thyroxine, triio-dothyronine, and reverse triiodothyronine. Endocrinology 116 : 1627-1635, 1985.

220. Leonard JL, Siegrist-Kaiser CA and Zuckerman CJ: Regulation of type II iodothyronine 5'-deiodinase by thyroid hormone. Inhibition of actin polymerization blocks enzyme inactivation in cAMP-stimulated glial cells. J Biol Chem 265: 940-946, 1990.

221. Savettieri G, Licata L, Catania C, Raneri R, Di Liegro I and Cestelli A: Synergistic effects of laminin and thyroid hormones on neuron polarity in culture. Neuroreport 10: 1269-1272, 1999.

222. Cestelli A, Di Liegro I, Castiglia D, Gristina R, Ferraro D, Salemi G and Savettieri G: Triiodothyronine-induced shortening of chromatin repeat length in neurons cultured in a chemically defined medium. J Neurochem 48: 1053-1059, 1987.

223. Cestelli A, Gristina R, Castiglia D, Di Liegro C, Savettieri G, Salemi G and Di Liegro I: The dynamic properties of neuronal chromatin are modulated by triiodothyronine. Neurochem Res 17: 1049-1055, 1992.

224. Scaturro M, Cestelli A, Castiglia D, Nastasi T and Di Liegro I: Posttranscriptional regulation of $\mathrm{H} 1$ zero and $\mathrm{H} 3.3 \mathrm{~B}$ histone genes in differentiating rat cortical neurons. Neurochem Res 20: 969-976, 1995.

225. Derrigo M, Cestelli A, Savettieri G and Di Liegro I: RNA-protein interactions in the control of stability and localization of messenger RNA. J Mol Med 5: 111-123, 2000.

226. Castiglia D, Scaturro M, Nastasi T, Cestelli A and Di Liegro I PIPPin, a putative RNA-binding protein specifically expressed in the rat brain. Biochem Biophys Res Commun 218: 390-394, 1996.

227. Nastasi T, Scaturro M, Bellafiore M, Raimondi L, Beccari S, Castelli A and Di Liegro I: PIPPin is a brain-specific protein that contains a cold-shock domain and binds specifically to $\mathrm{H} 1^{\circ}$ and H3.3 mRNAs. J Biol Chem 274: 24087-24093, 1999.

228. Nastasi T, Muzi P, Beccari S, Dolo V, Bologna M, Cestelli A and Di Liegro I: Specific neurons of brain cortex and cerebellum are PIPPin-positive. Neuroreport 11: 2233-2236, 2000.

229. Cestelli A, Savettieri G, Ferraro D and Vitale F: Formulation of a novel synthetic medium for selectively culturing rat CNS neurons. Dev Brain Res 22: 219-227, 1985

230. Bono E, Compagno V, Proia P, Raimondi L, Schiera G, Favaloro V, Campo V, Donatelli M and Di Liegro I: Thyroid hormones induce sumoylation of the cold shock domaincontaining protein PIPPin in developing rat brain and in cultured neurons. Endocrinology 148: 252-257, 2007.

231. Croteau W, Davey JC, Galton VA and St. Germain DL: Cloning of the mammalian type II iodothyronine deiodinase. A selenoprotein differentially expressed and regulated in human and rat brain and other tissues. J Clin Invest 98: 405-417, 1996.

232. Guadano-Ferraz A, Escamez MJ, Rausell E and Bernal J: Expression of type 2 iodothyronine deiodinase in hypothyroid rat brain indicates an important role of thyroid hormone in the development of specific primary sensory systems. J Neurosci 19: 3430-3439, 1999.

233. Tu HM, Kim SW, Salvatore D, Bartha T, Legradi G, Larsen PR and Lechan RM: Regional distribution of type 2 thyroxine deiodinase messenger ribonucleic acid in rat hypothalamus and pituitary and its regulation by thyroid hormone. Endocrinology 138: 3359-3368, 1997 .

234. Galton VA, Wood ET, St. Germain EA, Withrow CA, Aldrich G, St. Germain GM, Clark AS and St. Germain DL: Thyroid hormone homeostasis and action in the type 2 deiodinasedeficient rodent brain during development. Endocrinology 148: 3080-3088, 2007.

235. Samuels MH, Schuff KG, Carlson NE, Carello P and Janowsky JS: Health status, mood, and cognition in experimentally induced subclinical hypothyroidism. J Clin Endocrinol Metab 92 : 2545-2551, 2007

236. Miller KJ, Parsons TD, Whybrow PC, Van Herle K, Rasgon N, Van Herle A, Martinez D, Silverman DH and Bauer M: Verbal memory retrieval deficits associated with untreated hypothyroidism. J Neuropsychiatry Clin Neurosci 19: 132-138, 2007.

237. Bauer MS and Whybrow PC: Thyroid hormones and the central nervous system in affective illness: interactions that may have clinical significance. Integr Psychiatr 6: 75-100, 1988. 
238. Arem R and Cusi K: Thyroid function testing in psychiatric illness - usefulness and limitations. Trends Endocrinol Metab 8: 282-287, 1997.

239. Rivas M and Naranjo JR: Thyroid hormones, learning and memory. Genes Brain Behav 6 (Suppl 1): 40-44, 2007.

240. Desouza LA, Ladiwala U, Daniel SM, Agashe S, Vaidya R and Vaidya VA: Thyroid hormone regulates hippocampal neurogenesis in the adult rat brain. Mol Cell Neurosci 29: 414-426, 2005.

241. Clower CG: Organic affective syndromes associated with thyroid disfunction. Psychiatr Med 2: 177-181, 1984.

242. White AJ and Barraclough B: Thyroid disease and mental illness: a study of thyroid disease in psychiatric admissions. J Psychosom Res 32: 99-106, 1988.

243. Brunello N: Mood stabilizers: protecting the mood, protecting the brain. J Affect Disord 79: S15-S20, 2004.

244. Hahn C-G, Pawlyk AC, Whybrow PC, Gyulai L and TejaniButt SM: Lithium administration affects gene expression of thyroid hormone receptors in rat brain. Life Sci 64: 1793-1802, 1999.

245. Constantinou C, Bolaris S, Valcana T and Margarity M: Acute LiCl-treatment affects the cytoplasmic T4 availability and the expression pattern of thyroid hormone receptors in adult rat cerebral hemispheres. Neurosci Res 51: 235-241, 2005.

246. Constantinou C, Bolaris S, Valcana T and Margarity M: Diazepam affects the nuclear thyroid hormone receptor density and their expression levels in adult rat brain. Neurosci Res 52: 269-275, 2005.
247. Joffe RT, Sokolov TH and Singer W: Thyroid hormone treatment of depression. Thyroid 5: 235-239, 1995.

248. Prange AJ: Novel uses of thyroid hormones in patient with affective disorders. Thyroid 6: 537-543, 1996.

249. Kulikov AV and Zubkov EA: Chronic thyroxine treatment activates the 5-HT2A serotonin receptor in the mouse brain. Neurosci Lett 416: 307-309, 2007.

250. Franklin RJM: Why does remyelination fail in multiple sclerosis? Nat Rev 3: 705-714, 2002.

251. Calzà L, Fernandez M, Giuliani A, D'Intino G, Pirondi S, Sivilia S, Paradisi M, DeSordi N and Giardino L: Thyroid hormone and remyelination in adult central nervous system: a lesson from an inflammatory-demyelinating disease. Brain Res Rev 48: 339-346, 2005.

252. Davis RL, Shrimpton AE, Holohan PD, Bradshaw C, Feiglin D, Collins GH, Sonderegger P, Kinter J, Becker LM, Lacbawan F, Krasnewich D, Muenke M, Lawrence DA, Yerby MS, Shaw CM, Gooptu B, Elliott PR, Finch JT, Carrell RW and Lomas DA: Familial dementia caused by polymerization of mutant neuroserpin. Nature 401: 376-379, 1999.

253. Navarro-Yubero C, Cuadrado A, Sonderegger P and Munoz A: Neuroserpin is post-transcriptionally regulated by thyroid hormone. Mol Brain Res 123: 56-65, 2004. 